

\section{HARVARD UNIVERSITY.}

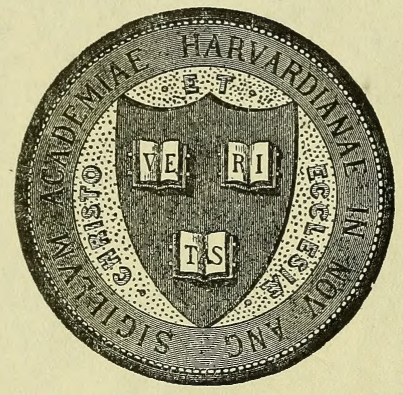

LIBRARY

OF THE

MUSEUM OF COMPARATIVE ZOÖLOGY 49,458

GIFT OF

B. Preston Clark

May 24, 1918 
49,458

\section{ENTOMOLOGY AND ZOOLOGY A T THE}

MASSACHUSETTS AGRICULTURAL COLLEGE

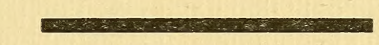

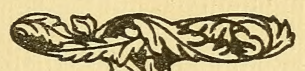

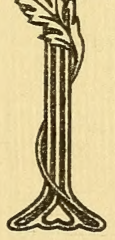

AMHERST, MASSACHUSETTS 
mingrigin

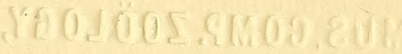

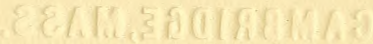




\title{
ENTOMOLOGY AND ZOOLOGY
}

\author{
AT THE \\ Massachusetts Agricultural College
}

AMHERST, MASS.

1911 
ISSUED BY THE

Massachusetts Agricultural College.

November, 1911. 


\section{FOREWORD}

This booklet has been compiled at the suggestion of alumni of the Massachusetts Agricultural College who were students under either Prof. Charles H. Fernald or Prof. Henry T. Fernald, or under both; and it is issued by the college in commemoration of the opening to collegiate use of the new entomological building, which is itself a memorial of the achievement of Prof. Charles H. Fernald in founding and developing entomological study in the college, and of Prof. Henry T. Fernald in taking up and carrying on his father's work.

The building was opened and dedicated on November 11, 1910, and was at that time practically complete. The program of the services of dedication was:

Henry James Clark,-Teacher and Investigator,

Dr. Frederick Tuckerman, '78, Amherst

Zoölogy and Entomology at the Massachusetts Agricultural College,

Dr. W. E. Hinds, '99, Auburn, Ala.

Presentation Remarks,

Hon. Frank A. Hosmer, Amherst

Dedicatory Address,

Dr. L. O. Howard, U. S. Entomologist, Washington, D. C.

The work of compiling has been made easy by the cordial assistance of all those who took part in the ceremonies, and of others. Dr. Howard's address has already been published (Science, Dec. 2, 1910; Entomological News, Vol. 22, No. 3, Page 97, March, 1911). In this booklet, space is lacking for more than a wholly inadequate paragraph of summary of Dr. Tuckerman's address. Dr. Hinds' paper is printed in full; but the limitations of space make necessary some condensation in the biographical sketches, and the author of these and the remaining (slight) alterations wishes here to assume responsibility for errors in fact or unhappinesses in expression that may have resulted from his work. 


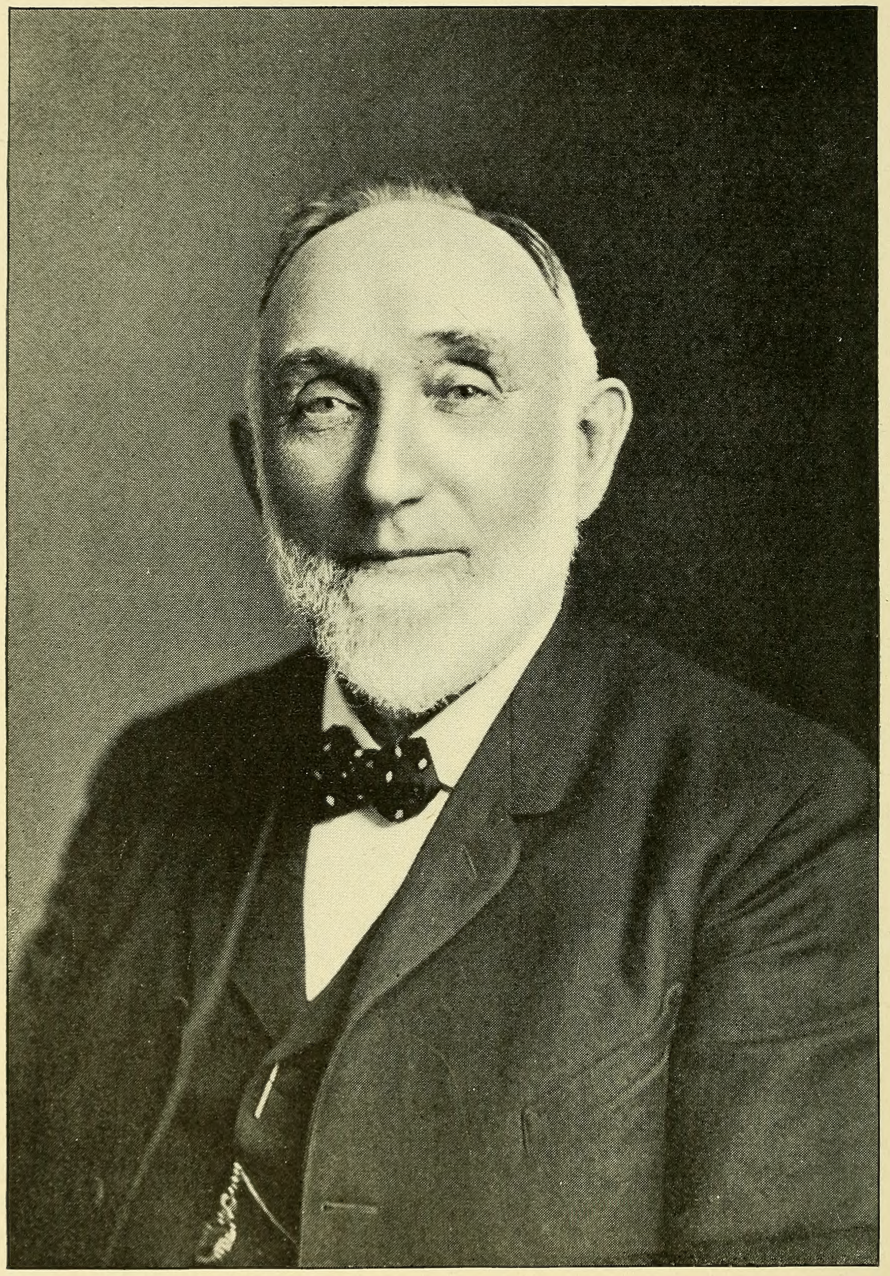

Charles Henry Fernald 


\section{CHARLES HENRY FERNALD}

At Fernald's Point, on Mount Desert, the largest of the many islands off the coast of Maine, is the Fernald homestead. It has been the homestead since 17r8. Here, close beside restless Atlantic waters, Charles Henry Fernald was born, March 16, 1838.

His father, Eben Fernald, was a successful farmer and ship-owner at a time when Maine was noted for sailing craft. His mother had taught school for a number of years before her marriage. In these two facts, part of his mental heritage may be fairly accounted for--his love of study, and his broad, hopeful, practical outlook. Upon the realities presented in his seaside home, this outlook began early to manifest itself.

In that time and neighborhood, opportunities for education were limited. School "held" about six weeks in winter, and two months in summer. But the lack of school and teacher was not enough to prevent the boy from acquiring about many subjects a knowledge far beyond that of the best educated people around him. The result was an early ability to choose his interests and direct his own study. His was largely "self-education"- the self-reliant, purposeful pursuit of knowledge that is typical of resolute and active minds-and in the course of years it made him thoroughly familiar with a wide range of subjects.

His dominant boyhood ambition, very naturally, was to become a ship captain; and he began preparing himself with the greatest earnestness. He learned to use a sextant (borrowed from a friend), taking observations of the sun by means of an artificial horizon formed by molasses in a plate. He soon became expert; but the lunar and stellar observations he found difficult without aid. It was the desire of his parents that he study law; but the law did not at all appeal to him, and he won consent to go to sea when fifteen years old. For six years his summers were spent on shipboard, and his winters in studying or teaching in the district school at home.

With the observation of the innumerable forms of exquisitely beautiful marine life-the corals, the sea fans, the sea feathers, shells-which he collected on his voyages, began his interest in natural history. He discovered that he could make pleasing drawings of these objects, and was especially struck with the fact that in making a drawing, he impressed the characteristics of the object deeply on his memory. In later years, this realization became an important element in his method as a successful teacher. 
Charles Fernald was more than a seaman; he was at the same time a student also. Hence he rose steadily in rank. At eighteen he was first mate, and at twenty-one was ready for a captaincy. Desiring still more thorough preparation, in order that he might command a ship of any size, he left the sea to enter the Maine Wesleyan Seminary and Female College. This was the largest preparatory school in the State.

In the seminary he found himself in an atmosphere entirely new to him-an atmosphere of education. It surprised, delighted and inspired him, aroused latent energies, created higher ambitions. Henceforth the call of knowledge was to be more potent than the call of the sea. He prepared to enter Bowdoin College as an advanced student.

But war intervened. The South seceded. His classmates enlisted. Most of them entered the army, but his sea-faring fitted him for and inclined him to the navy. For three years he had read and studied omnivorously, ranging freely beyond the required curriculum. Among the studies that he chose was music; the teacher was Miss Maria Elizabeth Smith, a student, later graduated from the college department. On August 20, 1862, they were married. Four days later he sailed from Boston on the U. S. Steamer Housatonic, a sister ship to the famous Kearsarge which sank the Confederate cruiser Alabama in the English Channel.

In the navy, promotion came steadily, the result of conscientious performance of the task in hand and of constant preparation for something beyond. On the Housatonic he was promoted to be master's mate, and later ensign; as ensign he served on several ships. On the U. S. Monitor Patapsco, he formed an intimate and lasting friendship with Lieut. W. T. Sampson, who remained in the navy, and during the Spanish-American War became Rear Admiral. Such might have been Prof. Fernald's ultimate destination also, had he chosen the career of a naval officer.

Young Fernald took on shipboard the text-books that he would have studied had he entered Bowdoin instead of the navy. In his three years of service, he found time to complete his college studies; and in $18 \% 1$ he was given the degree of Master of Arts by Bowdoin College.

On his return from the war, he was chosen principal of Litchfield Academy and taught with Mrs. Fernald as an assistant teacher. In the academy he found a large collection of rocks and minerals, of little service because most of its specimens were unnamed. To him it made small difference that he had no knowledge of either mineralogy or geology. Every spare moment at Litchfield he devoted to such books as he could procure to enable him to name the specimens.

This ability to study thoroughly without a teacher it was that fitted him to do the pioneer work which he later did in entomology. Whenever he found himself deficient in what seemed necessary to advanced work, he invariably got books and took up study by himself.. 
If books failed, he resorted to original study and to correspondence with eminent workers in the same field. Thus he was becoming more and more thoroughly familiar with a wide range of subjects, and acquainted personally with the leading men, both in this country and abroad.

After a year at Litchfield, he was called to take charge of Houlton Academy, then the largest academy in Maine. There he continued his geological studies, spending much time in the field, especially among the fossil-bearing rock deposits in northern and southeastern Maine. Finding that to study such rocks, he needed to know more of botany and zoölogy, he undertook a more exhaustive study of those subjects, though with no serious thought that he should ever teach them.

At this time, he got his first clear insight into entomology. It began with the breeding of mosquitoes, and led soon to the collecting of insects of all orders. In the new subject, he met more difficulties than in any other that he had attempted. Entomological literature in this country at that time was extremely fragmentary; entomologists were few and widely scattered. Following his earlier experience in the study of shells, he began the study of insect and fossil specimens by making drawings of them. His success was conspicuous; Prof. James Hall, then State Geologist of New York, tried in vain to procure him to make drawings of the fossils in the New York State collection.

In September, 1871, Prof. Fernald was called to the chair of Natural History in the newly established Maine state college, now the University of Maine. He was to teach botany, physical geography, human anatomy and physiology, comparative anatomy, veterinary science, and zoölogy, giving special attention to entomology, geology and mineralogy. Lest these few subjects should not occupy his energies, he was from time to time in his fifteen years' work at Maine, called upon to teach algebra, geometry, trigonometry, agriculture and horticulture.

During his connection with the Maine state college, he prepared and published "Grasses of Maine," "Butterflies of Maine," "Sphingidæ of New England," and a "Catalog of the Tortricidæ of North America," besides a number of shorter papers. His writings appeared in leading scientific journals in this country and in Europe. His vacations were frequently devoted to special study. Thus in $18 \% 2$ he was with the United States Fish Commission at Eastport, Maine; in 1873, he was studying zoölogy under Louis Agassiz in his famous summer school at Penikese Island. Whenever he had opportunity to visit a museum, he carried with him specimens he wished to compare or determine.

Insects now began to interest him increasingly. In its early years, Maine state college had both a winter and a summer vacation, and Prof. Fernald spent these periods principally in study. The winter of 1878 he spent in European travel and in a study of the world's greatest natural history museums. He carried a large col- 
lection of American insects, for comparison. He was most kindly received by foreign entomologists, among whom he made many lifelong friends. His studies in these museums gave him the basis for his "Catalog of the Tortricidæ of North America."

The winter of $18 \% 9$ he spent in Washington, D. C., in a study of the Microlepidoptera. The results of these studies appeared in the annual report of the Commissioner of Agriculture for 1880 . The United States Entomologist, Prof. J. H. Comstock, was making a study of North American scale insects, and in connection with this work Prof. Fernald became deeply interested in the Coccidæ. At this time also, began his intimate acquaintance with Dr. L. O. Howard, who was beginning his entomological work in the national Department of Agriculture, through which he has achieved such noteworthy success.

Other institutions now began to seek Prof. Fernald. The Iowa Agricultural College invited him to become its president. For some time he refused all offers. In 1886, however, he accepted the appointment as Professor of Zoölogy and Lecturer on Veterinary Science at the Massachusetts Agricultural College. In recognition of the breadth and the quality of his work, the trustees of the Maine state college conferred upon him the degree of $\mathrm{Ph}$. D. It is characteristic of the modesty of the man that he was always restive under the title of "Doctor," and preferred to be called and known by the simpler "Professor."

In the new position, Prof. Fernald found abundant opportunities for work, and but little material equipment. For his departments, two rooms were assigned in South College, then a new building. One of these was a lecture room, and the other was to contain the Natural History Museum. For laboratory work, no provision had been made, in either zoölogy or entomology; zoölogical laboratory work was begun in a borrowed room. The zoölogical specimens remained in the attic of the drill hall, where they had been hurriedly stored after the burning of the old South College building in 1885. Labels and specimens were in confusion. Practically all of the specimens had to be determined anew. In this and the work of rearranging the specimens, Mrs. Fernald was of great assistance.

When in 188\%, the experiment station was established, Prof. Fernald was made Entomologist, an appointment that added largely to his duties. In the summer of 1889 he went to Europe for further study in the museums, and while there was notified that the Gypsy Moth had been discovered in the eastern part of Massachusetts. He thereafter devoted all the time possible to the study of this insect in the different countries visited. In the organization of the state commission for the suppression of the moth, Prof. Fernald was given the supervision of the scientific part of the work. He made extensive studies, and has published a number of very valuable reports on the Gypsy and Brown-tail Moths. 
During the absence of President H. H. Goodell in 1892, Prof. Fernald served as acting President of the Massachusetts Agricultural College.

As a result of the entomological work made possible by the establishment of the experiment stations and the fight against the Gypsy Moth, the college work in entomology developed very rapidly. Prof. Fernald's time was increasingly given to it, and the work, first in veterinary science and later in zoölogy, was taken up by other men. In 1894, the department of entomology began the rapid but permanent growth that still goes on. In 1893, the trustees made entomology one of the advanced courses leading to the degree of Master of Science. Several students took part or all of this advanced work, and a strong demand arose for its further extension.

But such work could not be provided without permanent provision for additional help and accommodations, and this was hard to secure, as the college, with its limited appropriations, was already heavily taxed to carry on existing work. In 1898, the trustees authorized the conferring of the degree of Doctor of Philosophy upon the satisfactory completion of three years of post-graduate work in botany, chemistry, and entomology, and in the summer of 1899 , established a separate professorship of entomology. To the new chair they called Dr. Henry T. Fernald, then of the Pennsylvania state college. Prof. Charles Fernald, although his work consisted mainly in the development of the post-graduate courses in entomology, retained the title of Professor of Zoollogy. Under the able and sympathetic guidance of these two men, father and son, the entomological courses attracted more students than the laboratory facilities could possibly accommodate, and dozens of applicants had to be turned away.

The trustees in 1908 formally recognized the growing importance of the advanced work by establishing a graduate school, of which Prof. Fernald was made the director. In 1909 the legislature approved the service of the department of entomology by granting $\$ 80,000$ for a building for the departments of entomology, geology, and zoölogy, to which amount $\$ 15,000$ was later added for furnishings.

Prof. Fernald has seen his work consummated in the establishment of the graduate school and the erection of a department building wherein the equipment for entomological study is said to be unexcelled in the world. For in these is the fruition of his pioneer teaching in an unexplored region of scholarship. But another and lasting memorial is to be found in the hearts and lives of the large number of students who have received instruction and inspiration from him.

In June, 1910, after forty years of constant college teaching; Prof. Fernald felt constrained by failing health to retire from official college work, that he might devote his time and strength to the completion of studies in systematic entomology, in which he has been interested for many years. His special study has been the Microlepidoptera; and his authority on this group is recognized throughout 
the world. Among the more important of his publications on this group have been "A Catalog of the Tortricidæ of North America," "The Crambidæ of North America," "The Pterophoridæ of North America," and "The Genera of the Tortricidæ and Their Types." Other important papers are in process of completion.

A summary in brief of the work of a man who has achieved distinction in so many ways as has the subject of this sketch, must be inadequate. Perhaps he will longest be remembered as one of the great pioneer teachers of entomology; a man of highest Christian character; broad and sound in scholarship; rare in inspirational power. In economic entomology his greatest work has been done in the fight against the Gypsy and Brown-tail Moths; it has been unexcelled in the breadth and clearness of its conception of the problems, and in practical efficacy of methods. As a systematic entomologist, he has done work of the highest type in a large and difficult field.

We catch a hint of Prof. Fernald's own view of his work and of the motives which have guided him in it, in a few sentences from a recent letter of his to a friend:

"It has been a very great satisfaction to me to see entomology grow during the past forty years of my teaching, from a few lectures which I should now be ashamed to give to a class in a grammar school, into a thoroughly scientific course, with laboratory and research work of the most technical character, and appealing to and commanding the respect, not only of our own students but also of scientific men everywhere.

"There has been nothing in the work of my life that has given me greater pleasure than to see, from day to day and from year to year, the intellectual growth of the young men under my instruction, and later to learn of their successes in the great work of life. I have often wondered if I made a mistake in resigning from the navy at the close of the Civil War, rather than to have remained as did many of the volunteer officers, like myself; in which case, I should have been retired a few years ago with the rank of Rear Admiral. But I have consoled myself with the thought that it is better to help make men than to help kill them." 


\section{HENRY TORSEY FERNALD}

Henry T. Fernald was born at Litchfield, Maine, April 1\%, 1866, about a year after his father, Charles H. Fernald, had accepted the principalship of Litchfield Academy. From the time he was five years old until he was twenty, his father was professor in the Maine state college at Orono, and his youth was wholly spent in the atmosphere of the academy or college campus.

His early training was received entirely at home, and there he fitted for college. He entered the Maine state college and received from it the degree B. Sc. in 1885. The studies of greatest interest to him were chemistry, botany, zoölogy, and especially entomology; thus he followed closely in his father's footsteps. From his father he received instruction in entomology in the classroom and outside it. Most of his summers were spent at the old Fernald homestead, Fernald's Point, Mt. Desert Island, where he became acquainted with a large variety of both terrestrial and aquatic forms of animal life.

He pursued post-graduate study at Wesleyan University, Middletown, Conn., in 1885-1886, under the noted biologist Dr. H. W. Conn and the geologist Dr. W. N. Rice. In the fall of 1886 he entered Johns Hopkins University, but ill health forced his withdrawal after a short time. The spring of $188 \%$ found him in the Bahamas, attending the Johns Hopkins University Seaside School at Nassau, and the fall found him again at Johns Hopkins, where he took post-graduate work in morphology, physiology and botany under such eminent teachers as Drs. W. K. Brooks, H. N. Martin, and W. H. Howell. The Maine state college granted him its Master of Science degree in 1888, on presentation of a thesis. He continued his studies at Johns Hopkins, in his third year serving as laboratory assistant, and received the degree of Doctor of Philosophy in 1890. The training: which he received in zoölogy in its broad aspects was as good as could be obtained anywhere in the United States at that time. His major work was done in invertebrate zoölogy. His thesis, "The Relationships of Arthropods," was based on histological and other researches and was published in the "Biological Studies from the Johns Hopkins University," 1890.

Dr. Fernald had chosen teaching as his profession, and he went immediately as assistant professor of zoölogy to the Pennsylvania state college. After three years of efficient service, he was made professor of zoölogy there, and remained at that institution until the summer of 1899 . 
In these nine years, Dr. Fernald also filled a number of other important posts. In the summer school of the Brooklyn Institute of Arts and Sciences, at Cold Spring Harbor, Long Island, he served as instructor in invertebrate zoölogy for $1895-189 \%$; and he was also vice-director during the season of 189\%. In 1898-1899, he was state zoölogist of Pennsylvania.

When the professorship of entomology at the Massachusetts Agricultural College was offered to him in the summer of 1899, he saw an opportunity for larger and more distinctive work in entomology, and decided to accept the appointment, although it involved heavy financial sacrifice. In collaboration with his father, and with equal responsibility, he entered immediately upon the extension of the undergraduate and the development of the graduate courses in entomology. Entirely aside from the personal relationship-which naturally insured most sympathetic and harmonious co-operation-these two men were exceptionally well qualified, both by special training and varied experience, to divide the enlarged work of the department of entomology. For many years it had been their practice to pursue such different lines of study as to avoid duplication and to secure what was practically supplemental preparation for united effort. In the division of class work, Dr. Fernald, as the younger man, took practically all of the undergraduate work, and was most known to the junior and senior students. He also took the post-graduate courses in morphology and economic entomology. With the gradual failing in strength of Prof. C. H. Fernald in recent years, more and more of the lecture and laboratory work was assumed by Dr. Fernald, until he was carrying practically all of it, with no assistance except that of one post-graduate student in the laboratories with undergraduate classes, and in some parts of the experiment station work.

Besides carrying this excessive amount of classroom work, Dr. Fernald served as associate entomologist in the Massachusetts agricultural experiment station from 1899, becoming entomologist upon the resignation of his father in 1910 . He has also acted as Massachusetts state nursery inspector since 1902.

Although pressed by many and varied duties, he has still found time for considerable systematic work, especially in the orders Hemiptera and Hymenoptera. His published papers have dealt with a wide range of entomological subjects. Though most of them are comparatively brief, they number nearly one hundred articles, listed elsewhere in this pamphlet.

A review of Dr. Fernald's work at the Massachusetts Agricultural College cannot omit mention of his part in preparing the general plans for the splendid new building which has recently been completed, and in securing the appropriations needed to construct and equip the building as originally planned. The new building, the best that the state has yet given to the college, will stand as a testimonial to his 


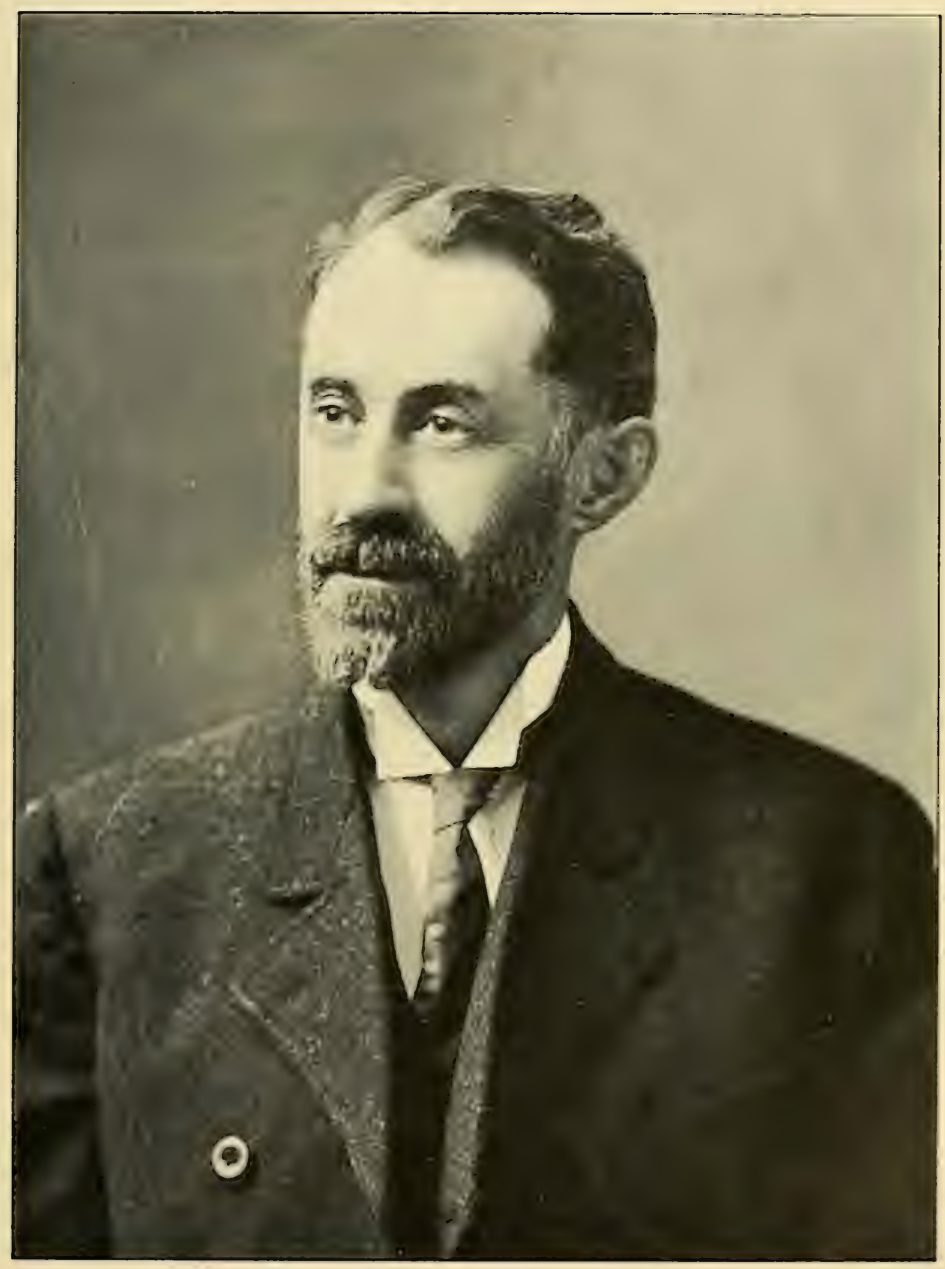

Prof. Henry T. Fernald 
constructive ability, as well as a memorial to the twenty-four years of service of Prof. Charles H. Fernald in the development of the department.

Dr. Fernald has long been an active member of a number of scientific organizations. Among others, he is a fellow of the American Association for the Advancement of Science, an active member of the American Association of Economic Entomologists, of the Entomological Society of America, and of the American Society of Naturalists. He is a member of Phi Kappa Phi and secured the organization of a chapter of this honor fraternity in the Massachusetts Agricultural College.

Upon his graduation from Johns Hopkins University, and when about to begin his work at Pennsylvania state college, he married, June 9, 1890, Miss Minna R. Simon of Baltimore. Their two daughters and one son make a very happy family circle.

Dr. Fernald's work has been primarily that of a teacher of entomology; and as a teacher he will be known through the men whom he has been so largely instrumental in preparing for practical economic work. Most of his students have chosen economic entomology as their profession; and they may be found in colleges and experiment stations throughout the United States, and as government entomologists in several foreign countries. In the continuance of his teaching, and in developing in the Massachusetts Agricultural College the department of entomology of which he is the head, Dr. Fernald has before him a long career of growing usefulness in a work and a science to which he is devoted with the earnest passion of the practical scholar. 


\title{
ZOOLOGY AND ENTOMOLOGY
}

\author{
at the
}

\section{MASSACHUSETTS AGRICULTURAL COLLEGE}

\author{
by
}

\author{
WARREN E. HINDS, PH. D.
}

M. A. C., 1899.

\section{Professor of Entomology Alabama Polytechnic Institute and Entomologist Alabama Agricultural Experi- ment Station, Auburn, Alabama.}

We meet today to dedicate this splendid structure for the use of the departments of zoölogy and entomology in this institution. It is fitting that in so doing we should recall something of the past, out of which this splendid achievement has grown. It is not a simple matter to prepare briefly a suitable review of all that has occurred in the past forty and more years, which has brought forth what we here see around us in the present. As has been said in regard to Carlyle's study of the life of Frederick the Great, in preparing that, he found that he had to study also the history of all Europe during that century.

When we speak of departments in an institution, such as we are here considering, we think not only of structures and equipment, of professors and courses of study; but also of the students and graduates who have gone out from the institution and whose work in later years is so closely linked with the training which they there received. While part remains, part is also going year by year, into the outside world, but that which goes is as closely connected with what remains as is the statue with the name and fame of its sculptor.

It is interesting to note that while the country was in the midst of the distractions and anxieties of Civil War, that Congress should have passed what is known as the Morrill Act of 1862, providing for the establishment of the agricultural and mechanical colleges. This al: marks one of the most significant steps in the educational history of our country. While the national appropriation was quickly accepted by the Massachusetts legislature, the preliminary work required in locating the institution, determining its general policies and courses of instruction, erecting buildings, securing professors, etc., delayed the opening of the college until the fall of $186 \%$. In the plan of organization as presented by President W. S. Clark, provision was made for a 
"department of natural history, including mineralogy, botany, zoölogy and geology." Thus was zoölogy recognized as one of the fundamental courses to be offered in its curriculum. As the first faculty numbered but four members, it seems to have fallen to the lot of Henry $\mathrm{H}$. Goodell to give the first instruction in the college, both in zoölogy and in entomology. While he was officially professor of modern languages and instructor in military tactics, he seems also to have been the general utility man in this versatile faculty of four.

During its early years the college frequently drew upon the faculty of Amherst College for lecturers in various subjects. Thus between 1869 and $18 \% 2$, it appears that Dr. Edward Hitchcock, always a constant friend to this institution, gave to the junior class a course of lectures on comparative anatomy. Between 1868 and 18\%6, Dr. A. S. Packard, Jr., then connected with the Peabody Academy of Science, and who was one of the most eminent entomologists of that time, gave to the juniors a course of lectures in the fall term, on useful and injurious insects. Doubtless the substance of his lectures may be found in the text-book which he published in 1869, under the title, "Guide to the Study of Insects." Although Dr. Packard seems to be remembered by some of his students more distinctly for certain peculiarities of speech than for the substance of his entomological lectures, there can be no question as to his ability as an instructor.

The first trained zoölogist actually to occupy a chair at the college was Henry James Clark, for fifteen years associated with Agassiz in the preparation of the great work, entitled "Contributions to the Natural History of the United States," and the foremost marine zoölogist and histologist of his time. Although seriously impaired in health, Prof. Clark applied himself with energy to teaching and the upbuilding of a museum of comparative and pathological anatomy. He taught human and comparative anatomy, physiology and zoölogy. These studies were to form the groundwork for a course in general and veterinary pathology. He also had in view graduate courses for advanced work and for special training. But his labors were soon interrupted by illness, and in July, 1873, at the age of forty-seven, his. useful life came to an end. A profound student of nature and an inspiring teacher, had his life been spared he would undoubtedly have left a marked impress on the college.

After Prof. Clark's death, we find Dr. Noah Cressy giving the instruction in zoölogy and several other subjects. His connection with the college seems to have been shortened by certain peculiarities. in his temperament and methods of instruction. It is said by one of his students, that in the midst of a lecture on anatomy, he succeeded. in securing the undivided attention of an uninterested student, by throwing at his head the bone with which he was illustrating his remarks. This incident resulted in the suspension of the entire class, because they objected seriously to Dr. Cressy's forcible methods. of instruction; but the matter was finally adjusted, and the class. finished its course. 
During the next ten years, from $18 \% 5$ to 1885 , most of the instruction in zoölogy seems to have been given by temporary lecturers, who were called in from outside the regular faculty. Again Amherst college helped out, and Profs. B. K. Emerson and John M. Tyler gave the zoölogical instruction. Dr. Frederick Tuckerman, a graduate of this college, class of '78, whom we are glad to have with us here today, was a medical graduate at Harvard in '82, and during the next few years lectured on human anatomy and physiology. The only instruction in entomology during this period appears to have been that given by Prof. S. T. Maynard in connection with horticultural courses, and a course in entomology given to the class of ' 83 by President P. A. Chadbourne.

The college was fortunate in receiving a natural history collection in its early days from the Massachusetts State Board of Agriculture, which had begun the collection of an exhibit of the birds, mammals, insects, etc., native to the state, some years before the establishment of the college. As early as 1858 this collection is said to have included about two-thirds of the native species of birds and nearly 2000 species of insects. Upon the establishment of the college it was decided to move this collection from Boston to the new institution and this transfer was made apparently, in 1867 or 1868 . Valuable additions to it were made by gift or purchase, so that it was considered worth more than $\$ 2000$ at the time that the building in which it was housed was burned in 1885. Through the prompt efforts of the students, some of this museum was removed from the burning building, but with considerable damage. Above the ashes of the old, there was quickly erected a new building, the South College of today, in which the zoölogical collection has since been stored, and where has been located the headquarters of the department of zoölogy. During the past twenty-five years the value of the equipment for the zoölogical department, excluding this collection, has increased to more than $\$ 10,000$.

The years 1886 and 1887 must be considered as marking an epochal point in the history of the college. In 1886, Henry H. Goodell became its president, and in his first annual report, the twenty-fourth of the college, he mentions the establishment of a new department in the domain of natural history. "The chair," said he, "has been admirably filled by the election of Charles H. Fernald, Ph. D." Prof. Fernald, as he has always modestly insisted that he would prefer to be called, was a graduate of Bowdoin College in 1871, then professor of natural history in the University of Maine until 1886, receiving his Doctor's degree from that institution. At one time it was his privilege also, to study with that incomparable teacher, Louis Agassiz, in his famous seaside school at Penikese. The chair which he took was entitled "Professor of Zoölogy and Lecturer on Veterinary Science." Grouped under this were the subjects of human anatomy and physiology, entomology, comparative anatomy of domestic animals and veterinary science, all of which subjects he is said by his students to have 


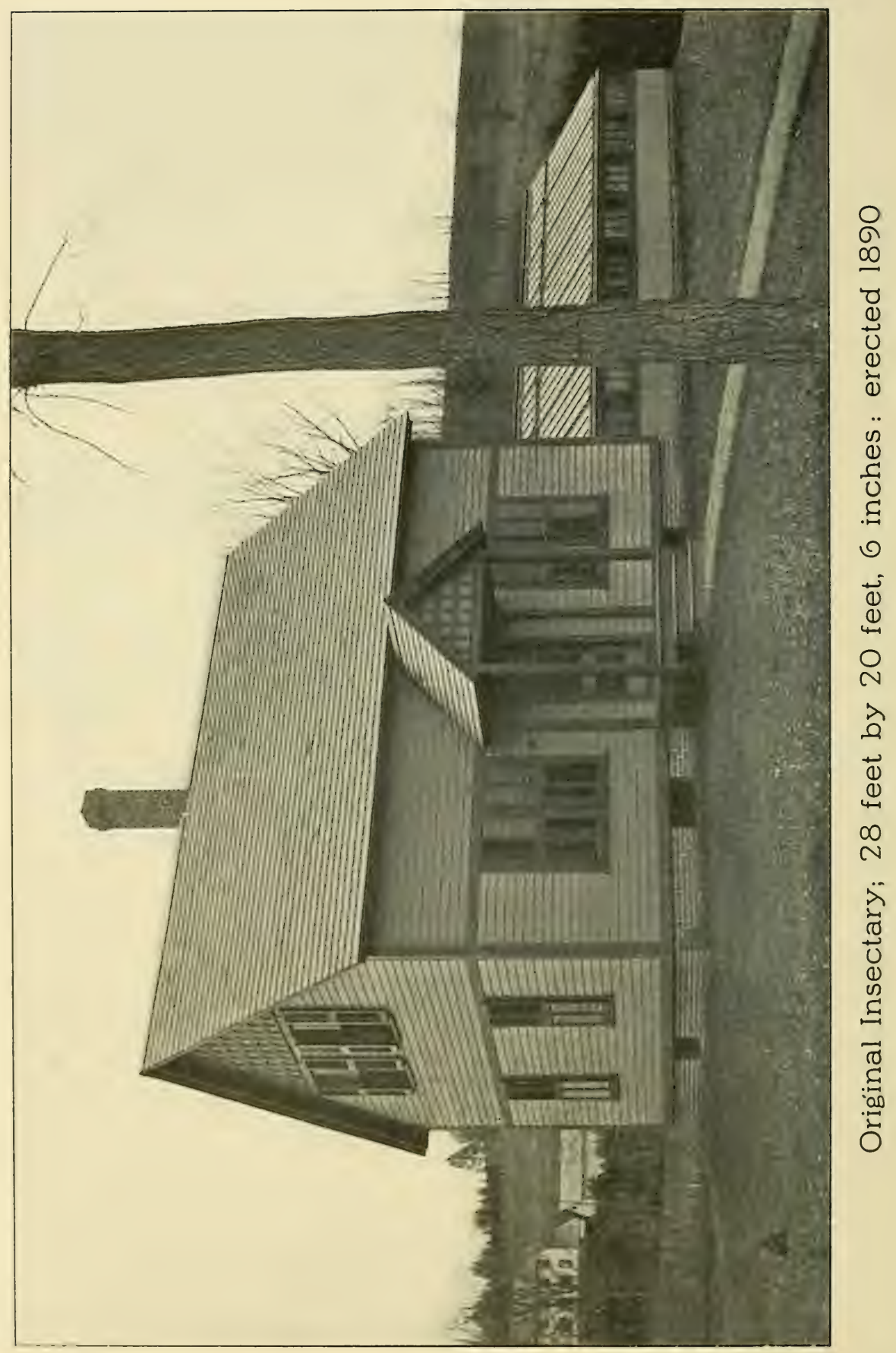


handled with marked ability, making them both interesting and profitable for the boys. But as one has said, "When I think of Prof. Fernald's teaching us the anatomy of domestic animals and veterinary science, in view of the later college work of the honored professor, the humor of the situation becomes, we think, apparent."

At that time, the department of natural history was confined entirely to two or three rooms in South College, and Prof. Fernald was in sole charge. In point of time as well as of importance, Prof. Fernald has been the first of the several factors which have cooperated in the upbuilding of these two departments as we find them today.

The year $188 \%$ was a notable one for all of the agricultural colleges, as it saw the passage of what was known as the Hatch Act, providing for a national appropriation to each state for the establishment and maintenance of an experiment station. The Massachusetts legislature accepted this appropriation very promptly, although Massachusetts had several years previously established a state experiment station of her own. As soon as Congress appropriated the money to carry this act into effect, a new station was organized as the experiment department of the agricultural college, and work was begun in April, 1888, with Prof. C. H. Fernald as entomologist. The establishment of the experiment station was the next important factor in developing economic entomology. Soon after this, President Goodell recommended to the trustees that a separate chair of veterinary science be established, and this was done in 1891. Previous to this time, zoölogy had been the principal subject of instruction, and entomology considered as but a minor, subsidiary branch of that general subject. The establishment of the experiment stations had, however, a stronger effect in developing the study of economic entomology, than in developing any other of the divisions which were originally included in them. Being a department of the college and officered by the professor of zoölogy, we must henceforward consider the department of entomology as embracing two closely connected divisions: one in the college as a course of instruction, the other in the experiment station dealing with investigations, experimentation and the diffusion of information.

The development of the experiment stations immediately opened a wide field for the activity of trained entomologists. In every state there arose a demand for men having a training such as no institution had previously been prepared to give. Teachers of entomology were called upon to fit men for this new field of work, while at the same time their experiment station duties forced them into experimental and investigational work for the control of insect pests. The growth of these branches of the work called for equipment such as had not previously existed and the need for quarters was first met here, through the construction of a small building with greenhouse attached, known as the "Insectary," which later became the ell of the present 
wooden structure. This was completed in 1890 at a cost of about $\$ 1200$ or $\$ 1400$, and its facilities became available for both college and station work.

A third powerful influence in furthering the study of entomology particularly became effective in the summer of 1889, when the Gypsy Moth first caused extensive damage in the eastern part of the state. It happened that Prof. Fernald was travelling in Europe at the time studying various collections and museums, and by a coincidence his son, Dr. H. T. Fernald, acting in his stead, was the first to identify this serious imported pest as occurring in this country. Upon his return to the United States, Prof. Fernald quickly prepared a special bulletin of information and advised that the state enter immediately upon a campaign for the suppression of the moths, as he realized that they were likely to become one of the most serious insect pests ever imported. The popular demand for action was so great that the legislature immediately appropriated $\$ 50,000$ and appointed a commission to conduct the work. The entomologist of the experiment station was made the director of the scientific part of the work, and in this capacity his advice was of immeasurable value in the fight which continued for the next ten years. By 1899, the moths were so well under control as to be rare in many sections where they had previously done enormous damage. This was of course evidence of the efficient work being done but it was the most critical time in the whole campaign of extermination, and it was exceedingly unfortunate that either personal or political interests should have raised the cry that there was no danger from the moths and that the expensive campaign was no longer needed. For four years no further action was taken to prevent the spread of the moths and during this period they multiplied enormously and scattered far beyond the limits of their previous distribution.

This fight against the Gypsy Moth has been mentioned especially because we believe it was an important factor in developing the first group of professional entomologists graduating from the college. A number of the students entered the Gypsy Moth fight, and this work doubtless had considerable influence in deciding their vocations. Another result of this campaign which has brought great credit to this department was the publication of an exceptionally complete and thorough report dealing with the life history of the pest and the fight made against it. At the time of this publication in 1896, the Gypsy Moth had been more thoroughly studied than had any other insect pest in America.

With the appointment of a professor of veterinary science in 1891, the professor of zoölogy was enabled to give his entire attention to zoölogical and entomological work. Even this, with the growth in the experiment station work and in the zoölogical museum, demanded more attention than one man could possibly give. The first assistant professor of zoölogy, Richard S. Lull, was appointed early in 1894. He was a graduate of Rutgers College in the class of '93, 
and had been engaged for a short period in the United States Bureau of Entomology. Prof. Lull's work at M. A. C. continued until the summer of 1906, when as a result of post-graduate work which he had done, in obtaining his Doctor's degree from Columbia University, he was appointed as assistant professor of vertebrate paleontology at Yale University and associate curator of vertebrate paleontology in the Peabody museum. Prof. Lull's work as a teacher was always very pleasing to his students. His genial good nature and consideration of his men won their strong personal loyalty, both in the class room and on the campus. As curator of the museum, he largely increased both its scope and its serviceability, making a complete rearrangement of the exhibits. It is a testimonial to the efficency of his work that his successor should be one of his own students, assistant professor Clarence E. Gordon.

Prof. Gordon was graduated from the Massachusetts Agricultural College in 1901; but he had already had a thorough business training that qualified him for administrative work and dealing with men. Two years later, he received from Boston University the degree B. Sc. Following three years as science master in Cushing Academy, he entered (1904) Columbia University. He was graduated A. M. from the School of Pure Science in 1905; was fellow in geology, 1905-1906; in 1906 was appointed to his work in the Massachusetts Agricultural College; and in 1910 was placed in charge of his department. His influence in the development of high ideals of scholarship and of college life is strongly felt.

For all those who have participated in the general zoölogical instruction may we say that their work has been along broad lines and for fundamental training, such as is needed for the later development of specialists, whether in the line of medicine, biology, entomology, or many other sciences. The fundamental value of such work cannot be overestimated, although it may sometimes be overlooked. May we never forget the need for broad, thorough scholarship and fundamental training as a preparation for later successful specialization. Since President Butterfield's connection with the college in 1906, the number of regular four-year course students has greatly increased, and laboratory facilities in all departments have rapidly become inadequate. New laboratories for zoölogical work were especially needed, and the accommodations now secured are excelled in very few institutions.

With this general review, we must leave the department of zoölogy and return to the year 1894, when the two-story wooden structure known commonly as the entomological laboratory was erected at a cost of about $\$ 3000$. This was a great improvement over previous accommodations for the entomological department, providing a well-lighted and equipped laboratory for microscopical work. This building served its purpose admirably for about ten years when the increased number of students in the college and the largely increased interest in the entomological courses offered, made it impossible to 


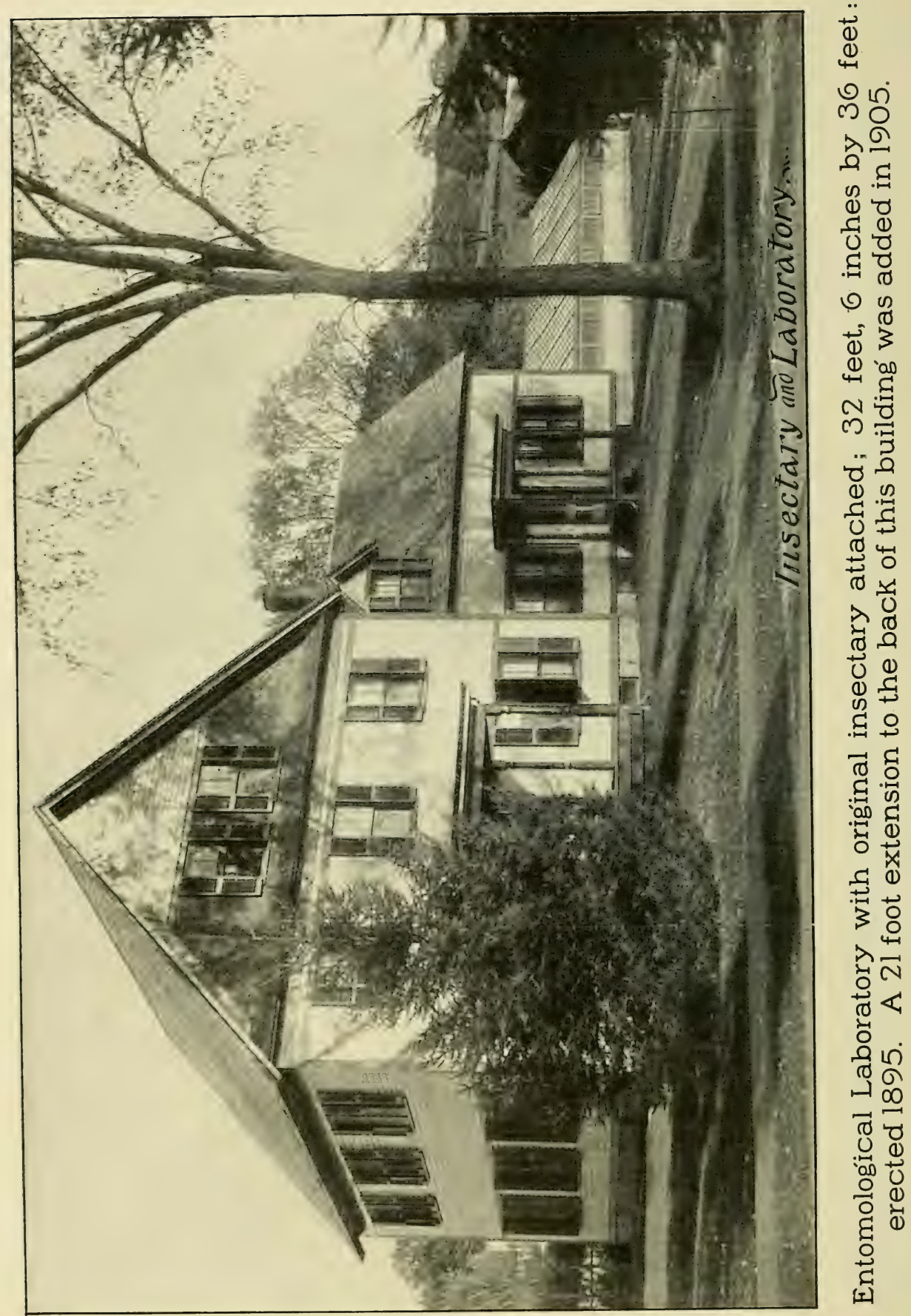


accommodate all of those who desired to elect entomological work. Year after year numbers of students had to be denied the privilege of taking work which the college, through its catalog, had advertised to give them. The emergency was met temporarily by a $\$ 3000$ addition or enlargement of the old building, completed in 1905 , but again crowding ensued and students had to be turned away. During the twenty years preceding, the entomological collection had grown rapidly and the equipment of the department increased until there was stored in this old two-story wooden building, materials valued at between $\$ 30,000$ and $\$ 35,000$, and a large number of type specimens of insects, which if lost, or damaged in any way, could never be replaced at any price.

These conditions were potent factors in securing from the legislature of 1909 an appropriation of $\$ 80,000$ for the erection of the building which we are dedicating.

In connection with this appropriation, we cannot refrain from mentioning the important part played by Hon. F. A. Hosmer, who was then Amherst's representative in the general assembly. His enthusiastic and able leadership was doubtless largely responsible for the immediate granting of the request for this building.

The development of the course of instruction preceded rather than followed the progress in building equipment. Although Prof. Lull undertook all of the class work in zoölogy, Prof. Fernald retained his position as head of the department until his retirement from the college in the summer of 1910 . During this period of seventeen years, the major part of his time and strength was given to the upbuilding of the department of entomology. Entomology was his first love and through his work in this field, his name was known internationally even before he came to Amherst. From 1894 to 1899 the entomological courses were being steadily elaborated, but still served mainly as minor subjects for men who proposed to follow some phase of horticulture or landscape gardening as their life work. The value of the work given was appreciated by the students, however, as is shown by the large numbers electing the course. Foundations were being laid for the next significant outgrowth which was being planned in the mind of Prof. Fernald, at least, to take the form of a graduate school. To make this graduate work possible, assistance both in the class room and in the experiment station was imperative, but those were years of struggle for the college in a financial way particularly, and increased funds could not be secured to provide increased teaching force. Few, indeed, of those who were watching the growth of the college at that time, had any idea of the personal financial sacrifice that was shared by father and son, when Dr. Henry T. Fernald accepted the position of professor of entomology in 1899 .

Henry Torsey Fernald was graduated from the University of Maine in 1885, just before his father left that institution to begin teaching at Amherst. After further study at Wesleyan, Maine, and Johns Hopkins Universities, he took his degree of $\mathrm{Ph}$. D. at Hopkins in 1890, and immediately accepted a very flattering opening as professor 
of zoölogy at the Pennsylvania state college, where he remained for nine years.

Probably no other two men could have been found anywhere in the world whose qualities of personality and education, combined, would have fitted them as well as were these two, to carry on successfully the post-graduate work in entomology which the Massachusetts Agricultural College now offered to students of this and other institutions. For many years the college had been giving the degree of M. Sc. for appropriate post-graduate work, particularly in the department of chemistry. The new plan as patiently, pleasantly, but persistently pushed forward by the Professors Fernald, outlined also, three years of required residential work with entomology as the only major at first available, and with botany and chemistry as minors, leading to the degree of $\mathrm{Ph}$. D. The subjects of botany, chemistry and horticulture have since been made available for major study and agriculture and zoölogy are also included in the list of minors. We have not time to consider here the scope of the work done by the post-graduate students. It is enough to say that a higher standard is set for the Doctor's degree, with entomology as a major, than is required in any other institution offering similar advanced work. The post-graduate courses now attract students from such other colleges as Amherst, Dartmouth, Brown and Harvard. Naturally, there existed at first, strong opposition to the idea of the graduate school but we believe that the results of ten years of trial show its wisdom and desirability.

It seems fitting indeed that when the trustees officially recognized this work, as they did in 1908, they should have made Prof. C. H. Fernald director of the graduate school. While we deeply regret that failing health has forced him to retire from active official connection with all college work, we are glad to record that he has been made honorary director of the graduate school. We can most heartily rejoice with him that he sees today so much of the priceless fruit of his many years of labor, and that the value of his teaching work has won for him recognition from the Carnegie Foundation.

We cannot close this review without noticing briefly a number of the men who were trained here for their later work in economic entomology. Upon their success has depended in large measure, the good name of the department of entomology, and the reputations of both Prof. Fernald and of Dr. Fernald, as teachers of entomologists. We may consider these men as forming three groups.

The first group, containing seven names, we may speak of as being the "Pioneer Group." These men were all more or less connected with the Gypsy Moth fight and received much of their valuable field training in that work. The first of these men, in point of time, is E. Porter Felt of the class of '91. After leaving the college he spent two full years at Cornell University, where post-graduate work in entomology was then possible, taking his degree of Sc. D. in 1894. As assistant to the late Dr. Lintner and successor to him as state entomologist of New York since 1898, Dr. Felt has been a leader in 
entomological work. The next class to send out entomologists was that of 1894, in which were two men whose work has brought much credit to themselves and to the college. Charles P. Lounsbury, after taking some advanced work as an assistant in the entomological laboratory, accepted the position of government entomologist for Cape Colony, South Africa, where he has since done work (especially with insects and ticks that may transmit diseases) which has made his name well known to scientific men throughout the world. His classmate, Archie H. Kirkland, was engaged in the Gypsy Moth fight until that work was suspended in 1899. When it was resumed in 1904, Governor Douglas turned immediately to Mr. Kirkland, and within ten days after the bill authorizing the work was signed, Mr. Kirkland was in active charge of the entire fight. Here he did most efficient service through several years that followed, in controlling this pest, although it had then spread far beyond any possibility of extermination:

In the class of 1895 there were four entomologists. Robert A. Cooley remained at the college as an assistant until, in 1898, he was called to become professor of zoölogy and entomology in the Montana Agricultural College, which position he has since filled with great credit. Another entomologist in this class, Albert F. Burgess, after having filled several state positions, has been returned by the Bureau of Entomology with which he is now connected, to take a leading part in the development of natural enemies which may aid in the control of the Gypsy and Brown-tail Moths. Henry A. Ballou entered the work of teaching, and entomology was included as one of his subjects. After several years, he returned to Amherst and availed himself of about two years of post-graduate study, leaving only to become government entomologist for the Barbadoes, where he is still stationed. The fourth man chose to open an entirely new field for entomological endeavor, and the success of the H. L. Frost Company has shown that commercial economic entomology has great possibilities in the future.

In the second group we have but five men to consider. These form the "Post-graduate" group, and are the men who have completed the required work and received the highest degree that the college can confer. While several subjects have been available for major study for the Doctor's degree, it is noticeable that all those who have yet taken it have been specializing in entomology. These men may have been characterized not so much by exceptional intelligence as by an unchangeable determination to hold on until the end was reached, while others yielded to the temptation of securing some alluring position, fearing that equally good opportunities might never again come their way.

Often has the speaker recalled a kindly interview in the office of Prof. Fernald, when he said, with a half-smile, as he has doubtless said to a score of other men since, "Our only fear for you is that you may not have the courage to hold out. We are not quite sure that you have the persistency to stick it through to the end." It was with no small feeling of pride that he received in 1902, the first degree of 
Ph. D. ever conferred by the college. He is sure that not one of those who have "stuck it through" has ever regretted for one moment that he did so. After more than five years of experience, investigating the Mexican cotton boll weevil in Texas, and three years as a state entomologist in Alabama, he is convinced that no more thorough preparation for the various branches of economic entomology is shown by the graduates of any college in the world than that of the graduates from this course in the Massachusetts Agricultural College.

The next graduate in this group was Austin W. Morrill, who went out in 1903, entering also the boll weevil investigation, and now serving as entomologist of the Arizona experiment station. One of the most valuable results of his work has been the establishment of a reliable system of fumigation treatment for citrus trees. In 1907 Ernest A. Back completed his course and immediately entered the Bureau of Entomology on white fly investigations. He has recently been appointed as state and station entomologist in Virginia. The following year Henry J. Franklin graduated. After a year as assistant entomologist in Minnesota, he was placed in charge of the Massachusetts station investigation of cranberry insects at Wareham, Massachusetts. The last man to receive the degree is Charles. W. Hooker, a graduate of Amherst College in 1906. Dr. Hooker entered the Bureau of Entomology work in connection with fruit insect investigations in 1909 .

In a third group we may include the entomological graduates from the regular four years' course during the past ten years, many of whom have taken part of the post-graduate courses before entering practical work. This is the largest group, and many of them have attained eminence in their work. We can take time to mention but a few of them. William A. Hooker of the class of '99, took part of the postgraduate work, engaged in the boll weevil and cattle tick investigations in Texas for several years and is now editor of the Department of Economic Zoology and Entomology for the Experiment Station Record. Ralph I. Smith, of 1901, has occupied state positions in Maryland and Georgia and is now professor of zoölogy and entomology at the North Carolina Agricultural and Mechanical College. Harold E. Hodgkiss of '02 pursued post-graduate study for a time and then became assistant entomologist at the New York experiment station. Another government entomologist was found in the class of 1903 in Winthrop $\mathrm{V}$. Tower, who has been station entomologist for Porto Rico for several years.

Among the more recent graduates, a number have taken part of the post-graduate training. At least seven are now engaged in the National Bureau of Entomology; five are assistants in as many experiment stations; one is government entomologist in Uganda, British East Africa; several have engaged in commercial work, following the lead of H. L. Frost, and eight are still engaged in post-graduate work for their degrees. Surely the reputation of the college for the training of entomologists will be greatly enhanced when this group of younger men shall have had time to produce positive results. 
In this hurried sketch of these two departments we have been obliged to omit many factors which have helped in their up-building, but we cannot afford to close without alluding to the part that Mrs. C. H. Fernald has contributed. In the department of entomology, one of the most valuable items is a most carefully compiled card catalog containing more than 60,000 references to entomological literature. In several subjects this is particularly complete, and embraces the publications of the world. Mrs. Fernald has been largely responsible for the preparation of this immense index. Her "Catalogue of the Coccidæ of the World," published in 1903, has attracted high praise for both its completeness and its correctness. In many other ways, also, has she contributed invaluable assistance in furthering the work in which Prof. Fernald was engaged.

Still another factor of importance is found in the very exceptional library facilities afforded entomological students in Amherst. For many years the Massachusetts Agricultural College and Amherst College librarians have worked together to prevent the needless duplication of expensive works, and the two libraries have been made thus to supplement each other in important particulars. Besides these libraries the experiment station has a very valuable collection of the works that are of primarily economic importance. In addition to all these the private libraries of both the professors have always been open to the use of students. Furthermore, if any book was needed by a student in his work and it was not obtainable otherwise, the private purse of the professor always provided it. Thus has he built up, for his own and his students' use, a private library of between 2500 and 3000 volumes, some of which cannot be duplicated in the United States.

In closing, I must express for myself and for my fellow students in entomology, our deep appreciation of the self-sacrificing service which Prof. Charles H. Fernald has given to this institution during these twenty-four years. Twenty-five years ago, President Greenough wrote, "Progressive manhood should be the object of every college." Huxley claimed that "Productive thinking is the chief means as well as the end of education." We have had before us the living demonstration and exemplification of the truth of both these claims, and happy shall we be if we also may be able to show their fruits in our own living and thinking.

May this building long serve to facilitate the work which he has been largely instrumental in building up, especially in the department of entomology. His real monument, of which this splendid building is but a visible sign, may be found in the lives and work of those students whose interest he has fired, whose minds he has stored with useful knowledge and whose hands he has trained to skillful service. To each of us, he has been both a teacher and a warm personal friend, to whom we owe very much of the best of what we are or have been able to accomplish for our fellow-men.

To the long continued advancement of such work as we have thus but imperfectly reviewed, do we dedicate this building, and our lives. 


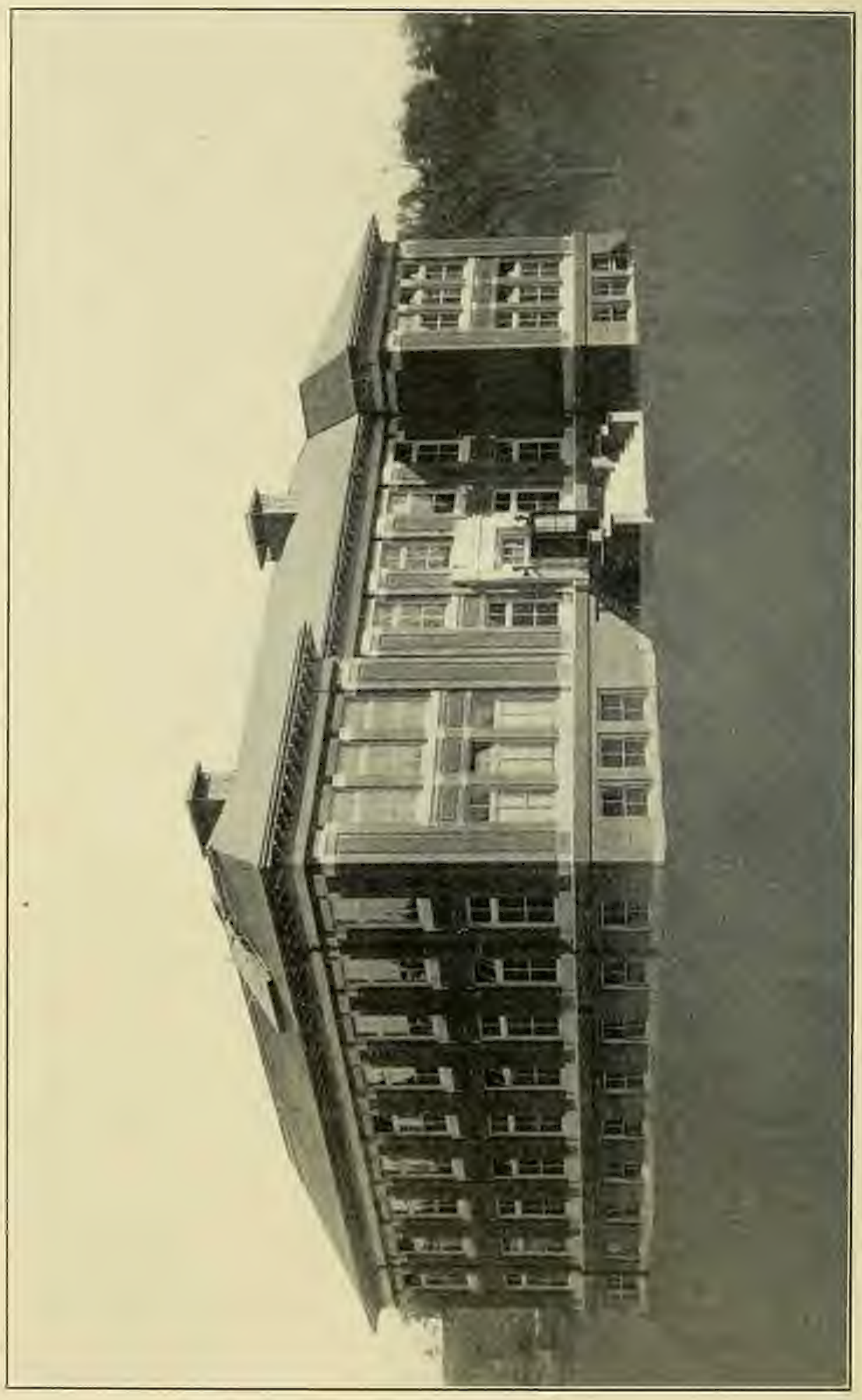

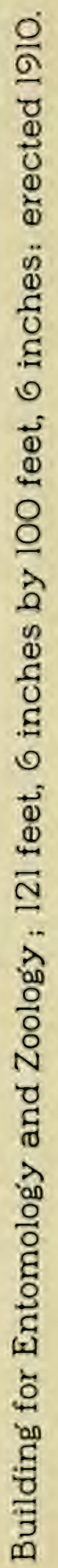




\section{LABORATORY FOR ENTOMOLOGY AND ZOOLOGY}

The new building for entomology and zoölogy which. was dedicated November 11; 1910, is located slightly north of; and a little farther from the street than the old entomological laboratory. It is constructed of brick, with stone trimmings, a steel frame, reinforced cement floors and a slate roof, and is considered to be entirely fireproof. It is in the form of an $\mathrm{H}$, the cross bar being carried toward the front, thus giving a central building and two wings. It has a frontage of 124 feet, while the wings are 100 feet in length.

The central portion in front is devoted to offices, supply rooms, and a library on the second floor. Behind is an amphitheater rising from the basement and accommodating about 180 persons. Above this, on the second floor, is the insect room, twenty by forty feet, and a filing and stenographer's room. The north wing contains the zoölogical laboratory and a room for microtomy on the first floor, and the senior and graduate entomological laboratories on the second floor. In the south wing are the zoölogical museum, and three rooms for the entomological work of the experiment station, one of which is connected with the greenhouse for experimental work on insects. On the second floor of this wing are the gallery of the museum, an advanced lecture room, accommodating sixty persons, and a graduate laboratory for zoölogy. In the basement, besides the amphitheater, are rooms for determinative mineralogy and geology, for the rock collections, a pump and apparatus room, an insecticide analysis room, and toilet and fan rooms. In the attic are rooms for photography and developing, a storage room and the janitors' quarters.

The building is lighted by electricity and heated by steam from the central heat and light plant of the college.

The building is provided with spacious museum rooms for the exhibition of the collections in zoölogy and geology. The collections have been built up for illustrative purposes in the courses of instruction in these subjects and are already large and diversified for many branches of the work. Further materials needed to make the collections more effective instruments of instruction are constantly being added. The department has been fortunate during the past year in receiving valuable gifts from friends and alumni for the museum, of which notice has already been made.

The zoölogical museum consists of a main floor-space on the ground floor of the building and a large gallery floor-space which at present is only partly occupied and which permits of considerable further growth. The 12,000 specimens comprising the collection, many of which, of course, are small, are exhibited in sixteen large cases.

On the basement floor is a geological museum provided with six large cases for the exhibition of the geological collections which are steadily growing in size and in consequence usefulness for purposes of instruction. 
The insect collection is estimated to consist of perhaps 100,000 specimens at the present time. Most of these are pinned, though some alcoholic material is also available, particularly in certain groups. Many of the smaller insects are mounted on slides for microscopic study, and of these there are several thousand.

The main pinned collection is arranged systematically in museum trays, and here, as far as possible, the entire life history of each insect is represented, this being particularly the case with the Lepidoptera. Duplicate material, also systematically arranged, is stored partly in museum trays, partly in Schmitt boxes.

Between 800 and 900 types of various grades are also in the collection, kept separate from the rest of the material, and stored in a Brock metal cabinet. A list of these types is given elsewhere in this pamphlet.

Naturally the collection is most complete in those forms which occur in the eastern United States. Other parts of the country are represented to a considerable extent, however, particularly in the case of insects which are of economic importancé. Considerable material from Central and South America and the West Indies is also present, together with a small amount from the Old World, much of this exotic material having been received through the kindness of graduates of the college.

The collection is kept in a large room on the second floor of the building, directly connecting with both the senior and graduate entomological laboratories, and is thus easily accessible for study. 


\section{COURSES IN ENTOMOLOGY}

\section{A. Undergraduate.}

Undergraduate entomology begins in the junior year. An introductory course in the subject is given, adapted to the needs of the various students electing it. Many of these expect to take no further work in the subject, specializing in other lines, and accordingly the topics chosen are such as should prove most useful in general.

A brief consideration of the structure of insects, external and internal, is therefore followed by an outline of different kinds of metamorphosis, and this by a systematic treatment of the various orders, particular stress being laid upon those of greatest economic importance. Under each of these groups the most serious pests are considered in some detail, their different stages being discussed, the times at which they can be most successfully attacked, and the methods for their control. Spraying materials and methods of applying them are also taken up to some extent. Field and laboratory work given as a part of this course during that portion of the time when the season will permit, are devoted to examination and recognition of the work of different insects out of doors, to collecting, methods of pinning, spreading and mounting of insects, and a general classification of them.

In the senior year, a course is offered those students who desire to become more thoroughly acquainted with the insects injurious to special crops. In this work the student studies the external structure of insects of each of the larger groups, as a basis upon which to intelligently use keys for the determination of different insects, in order that he may be able to learn the identity of any pest he may subsequently meet. This is followed by the actual identification of a number of insects in each order, to train the student where to find and how to use the analytical keys. He then selects the most serious pests of the crops which he plans to raise, for special study, using the different articles available on these insects, and studying specimens of the insects in the collections. The results of these studies are brought together in note books which are retained by the student for reference after leaving college and beginning work for himself. During the year a thorough course on the various insecticides, and methods of applying them is also given.

For those planning to become professional entomologists, instead of studying the pests of some special crop, the worst pests of all kinds are taken up, followed by studies on parasitism, group relations, etc., giving the broader views needed for the general entomologist. Field work in connection with this is given wherever it is possible, and practical experience is emphasized. 


\section{B. Graduate.}

Graduate students taking entomology as a major subject are expected to have received the undergraduate work given at the Massachusetts Agricultural College, or its equivalent, or to make up that work before receiving credit for advanced work. Students for the degree $\mathrm{Ph}$. $\mathrm{D}$. are required to spend at least three years in residence, devoting at least twenty hours per week to the work. Students taking entomology as a minor subject are required to spend from twelve to sixteen hours each week for a year and a half.

The importance of some knowledge of all aspects of entomology to the professional entomologist is recognized by giving courses of lectures to the graduate students on the subjects named below. It is not implied that these courses are all by any means exhaustive, but rather that in connection with about 15,000 pages of required reading, each student will acquire a fair knowledge at least, of all aspects of his profession. In addition to this he will be expected to specialize in certain lines and to prepare a thesis, generally in two or three subjects, which will be not only original, but a distinct contribution to knowledge. His special work may include some subject in morphology, the systematic classification of some group, the preparation of the life history of some insect and some problem connected with insect control, the relative proportion between these topics being dependent upon circumstances.

Frequent seminars, at which reports on current literature, important general topics, and subjects assigned for report by the teachers, are also held, and the student is expected to acquire familiarity with the literature of entomology and to learn how to abstract and present the results of his reading and work.

The following list of topics is presented to graduate students, either by lectures or by laboratory or field training, in addition to the thesis work.

Morphology.-Embryology; life history and transformations; histology; phylogeny and the relation of insects to other arthropods; hermaphroditism; hybrids; parthenogenesis ; pedogenesis ; heterogamy ; chemistry of colors of insects; luminosity; deformities of insects; variation; duration of life.

Ecology.-Dimorphism; polymorphism ; warning coloration ; mimicry; insect architecture; fertilization of plants by insects; instincts of insects; insect products of value to man; geographical distribution in the different faunal regions; methods of distribution; insect migration; geological history of insects; insects as disseminators of disease; enemies of insects, vegetable and animal, including parasites.

Economic entomology.-General principles; insecticides; apparatus; special cases; photographs of insects and their work; methods of drawing for illustrations; field work on insects and study of life histories; legislation concerning insects. 
Systematic entomology.-History of entomology, including classifications and the principles of classification; laws governing nomenclature; literature, how to find and use it; indexing literature; number of insects in collections and in existence (estimated); lives of prominent entomologists; methods of collecting, preparing, preserving and shipping insects; important collections of insects. 


\title{
TYPES DEPOSITED IN THE COLLECTION OF THE MASSACHUSETTS AGRICULTURAL COLLEGE
}

\author{
January 1, 1911
}

These types have been designated in accordance with the definitions given in the Merton Rules. In a few cases where it is doubtful whether a specimen is a cotype or a paratype, the lower grade of the two has been designated.

\section{LIST OF TYPES}

Pinned specimens:

\section{ORTHOPTERA}

Spharagemon aequale scudderi Morse, C 2.

Spharagemon sexatile Morse, C 2.

\section{THYSANOPTERA}

Mounted on slides:

Acanthothrips magnafemoralis Hinds, male, T 1.

Acanthothrips magnafemoralis Frank., female, C 2.

Aeolothrips bicolor Hinds, C 7, M 1.

Aleurodothrips fasciapennis Frank., C 1.

Anthothrips gowdeyi Frank., C 11, P 8.

Cephalothrips yuccæ Hinds, C 6, M 9.

Chirothrips obesus Hinds, C 1.

Cryptothrips aspersus Hinds, C 3, H 1.

Cryptothrips fasciapennis Frank., female, T 1.

Ctenothrips bridwelli Frank., C 3.

Eurythrips ampliventralis Hinds, C 4.

Eurythrips osborni Hinds, C \%, M 3.

Euthrips fuscus Hinds, C 19.

Euthrips insularis Frank., C 18, P 46.

Euthrips nicotianæ Hinds, C 3.

Heliothrips fasciapennis Hinds, C 1.

Heliothrips rubrocinctus Giard, male, Frank., T 1.

Limothrips avenæ Hinds, C 3, M 4.

Malacothrips zonatus Hinds, C 3.

Phlœothrips nigra Osb., $\mathrm{H} 6$.

Phlœothrips pergandei Hinds, T 1.

Rhaphidothrips fuscipennis Hinds, C 2, M 1.

Sericothrips cingulatus Hinds, C 14.

Sericothrips (?) perplexus Beach (Thrips), H 8.

Thrips striata Osb. (Anaphothrips), H 6 . 
Thrips variabilis var. a. Beach (Sericothrips), H 2.

Thrips variabilis var. d. Beach (Sericothrips), H 1.

Trichothrips ambitus Hinds, T 1.

Trichothrips beachi Hinds, T 1.

Trichothrips niger Frank., female, T 1.

\section{Coccidae.}

\section{HEMIPTERA}

Pinned specimens:

Aspidiotus liquidambaris Kotinsky, C 1.

Aspidiotus paulistus Hempel (Chrysomphalus), C 4.

Aspidiotus sabalis Comst. (Comstockiella), C 2.

Aulacaspis miranda Ck1l. (Diaspis), C 1.

Capulinia crateraformans Hempel, C 4.

Capulinia jaboticabæ v. Ihering, C 2.

Ceroplastes communis Hempel, C 1.

Ceroplastes confluens Ck1l. \& Tins., C 2.

Ceroplastes cuneatus Hempel, C 2.

Ceroplastes floridensis Comst., C 3.

Ceroplastes formicarius Hempel, C 3.

Ceroplastes grandis Hempel, C 6 .

Ceroplastes lucidus Hempel, C 3.

Ceroplastes nevæsi Hempel, C 3.

Ceroplastes purpureus Hempel, C 3 .

Ceroplastes speciosus Hempel, C 2.

Ceroplastes variegatus Hempel, C 3.

Chionaspis aucubæ Cooley mss., C 1 .

Chionaspis caryæ Cooley, C 1.

Chionaspis cockerelli Cooley (Phenacaspis), C 1.

Chionaspis corni Cooley, C 1.

Chionaspis gleditsiæ Sand., C 1.

Chionaspis latissima Ck11. (Phenacaspis), C 1.

Chionaspis latus Ck1l. (Hemichionaspis aspidistræ Sign.), C 1.

Chionaspis lintneri betulæ Cooley, C 2.

Chionaspis longiloba Cooley, C 1.

Chionaspis lounsburyi Cooley (Phenacaspis), C 1.

Chionaspis major Ck1l., C 3.

Chionaspis piceus Sand., C 1.

Chionaspis pinifoliæ heterophyllæ Cooley, C 6.

Cryptokermes brasiliensis Hempel, C 5.

Diaspis australis Hempel, C 1.

Diaspidistis multilobis Hempel, C 4.

Edwallia rugosa Hempel, C 1.

Eriococcus brasiliensis Ck11., C 2.

Eriococcus perplexus Hempel, C 5.

Icerya brasiliensis Hempel, C 6 .

Icerya hempeli Ck1l. (Paleococcus), C 3.

Lecaniodiaspis rugosa Hempel, C 1. 
Lecanium campomanesiæ Hempel (Mesolecanium?), C 2.

Lecanium discoides Hempel (Saissetia), C 1.

Lecanium obscurum Hempel (Mesolecanium?), C 2.

Lecanium ornatum Hempel (Stictolecanium), C 2.

Lichtensia attenuata Hempel (Alichtensia), C 1.

Mytilaspis albus Ck1l. (Lepidosaphes), C 1.

Pulvinaria aurantii Ckll., C 1.

Pulvinaria eugeniæ Hempel, C 3.

Pulvinaria ficus Hempel, C 5.

Pulvinaria japonica Ck11. (Takahashia), C 1.

Pulvinaria lutea Ck1l. (Litchtensia), C 1 .

Pulvinaria marmorata Ckll. (Pulvinaria bigeloviæ marmorata), C 1.

Pulvinaria polygonota Ck11., C 1.

Pseudaonidia clavigera Ckll., C 1.

Pseudischnaspis linearis Hempel, C 3.

Stigmacoccus asper Hempel, C. 5.

Solenococcus baccharidis Hempel, C 4.

Tachardia cydoniæ Hempel, C 1.

Tachardia fulvoradiata Ckll., C 3.

Tachardia ingæ Hempel, C 1.

Tachardia parva Hempel, C 1.

Tachardia rosæ Hempel, C 1.

Tachardia rubra Hempel, C 1.

Tectopulvinaria albata Hempel, C 1.

Tectococcus ovatus Hempel, C 4.

Coccidae.

Mounted on slides:

Aspidiotus duplex Ckll. (Pseudaonidia), M 2.

Aspidiotus forbesi Johns., M 1.

Aspidiotus howardi Ck11., C 1.

Aspidiotus juglans-regiæ Comst., C 2.

Aspidiotus obscuŕus Comst. (Chrysomphalus), C 2.

Aspidiotus perseæ Comst. (Chrysomphalus), C 2.

Chionaspis acuminata Green, M 2.

Chionaspis africana Cool. mss., C 2.

Chionaspis arundinariæ Green, M 2.

Chionaspis aucubæ Cool. mss., C 5.

Chionaspis berlesii Leon, M 1.

Chionaspis bruneri Ck11., C 3.

Chionaspis caryæ Cool., C 3.

Chionaspis chinensis Ck1l. (Phenacaspis), T 1.

Chionaspis cockerelli Cool. (Phenacaspis), C 4, M 2.

Chionaspis corni Cool., C 9.

Chionaspis dilatata Green (Phenacaspis), M 3.

Chionaspis dubia Mask. (Phenacaspis), M \% .

Chionaspis dysoxyli Mask., M 1.

Chionaspis elæagni Green, M 4.

Chionaspis elongata Green, M 3. 
Chionaspis ethelæ Fuller, T 1.

Chionaspis eugeniæ Mask. (Phenacaspis), M 6.

Chionaspis flava Green (Phenacaspis), M 2.

Chionaspis fodiens Green, M 2.

Chionaspis galliformens Green, M 2.

Chionaspis graminis Green, M 4.

Chionaspis graminis divergens Green, M 5 .

Chionaspis herbæ Green, M 3.

Chionaspis howardi Cool., C 1.

Chionaspis latissima Ck11. (Phenacaspis), C 2.

Chionaspis lintneri Comst., T 1, C 1.

Chionaspis lintneri betulæ Cool., C 3 .

Chionaspis litzæa Green (Phenacaspis), M 2.

Chionaspis longiloba Cool., C 5.

Chionaspis lounsburyi Cool. (Phenacaspis), C 7.

Chionaspis madiunensis Zehnt., M 8.

Chionaspis megaloba Green (Phenacaspis), M 4.

Chionaspis nitida Mask., M 2.

Chionaspis nyssæ Comst. (Phenacaspis), C 1.

Chionaspis ortholobis Comst., C 2.

Chionaspis permutans Green, M 1.

Chionaspis pinifoliæ heterophyllæ Cool., T 1, C 4.

Chionaspis platani Cool., C $\%$.

Chionaspis sacchari-folii Zehnt., M 8.

Chionaspis simplex Green, M 2.

Chionaspis spartinæ Comst., C 4.

Chionaspis stanotophri Cool., C 4.

Chionaspis tegalensis Zehnt., M 7.

Chionaspis varicosa Green (Phenacaspis), M 2.

Chionaspis vitis Green, $\mathrm{M} \%$.

Chionaspis wistariæ Cool., C 5.

Chionaspis xanthorrhoeæ Fuller, T 1.

Chionaspis xerotidis Mask. (Phenacaspis), M 3.

Diaspis echinocacti opuntiæ Ck1l., M 2.

Diaspis miranda Ckll., C 3.

Hemichionaspis dracænæ Cool., C 2.

Hemichionaspis exercitata Green (Hemichionaspis theæ), M 2.

Hemichionaspis latus Ck11. (Hemichionaspis aspidistræ), C 5.

Hemichionaspis minor strachani Cool., C 4.

Lepidosaphes pyriformis Mask., M 1.

Leucaspis cordylinidis Mask., M 3.

Parlatoria pergandii crotonis Ckll. (P. crotonis), C 2.

Pseudoparlatoria ostreata Ck11., M 2.

Pseudoparlatoria serrulata Towns. \& Ckll., C 2.

Pulvinaria phaiæ Lull (P. floccifera), C 11. 
Aleyrodidae.

Pinned specimens :

Aleyrodes fernaldi Morrill, T 1, C 4.

Aleyrodes mori-maculata Morrill, C 4.

Aleyrodes packardi Morrill, T 1, C 2, M 5.

Mounted on slides:

Aleyrodes betheli Ck1l. mss., C 1.

Aleyrodes dugesii Ckll., M 1.

Aleyrodes mori maculata Morrill, C 1.

Heteroptera.

Pinned specimens:

Dysdercus fernaldi Ballou, C 1.

Dysdercus howardi Ballou, C 4.

Leptobyrsa explanata Heid., H 2.

Phymata salicis Ckll., C 1.

\section{LEPIDOPTERA}

Pinned specimens:

Tephroclystis miserulata Grt., H 1.

\section{DIPTERA}

Pinned specimens:

Achætoneura fernaldi Willst. (Tachina mella Walk.), C 8.

Asilus auratus Johns., C 1.

Asilus erythrocnemius Hine, P 12.

Asilus latipennis Hine, P 2.

Asilus occidentalis Hine, P 2.

Asilus piceous Hine, P 3.

Cecidomyia foliora Russ. \& Hook., C 9, P 12.

Cophura fallii Back, C 2.

Cyrtopogon callipedilus Loew, H 1.

Cyrtopogon chrysopogon Loew, H 3.

Cyrtopogon marginalis Loew, H 2.

Cyrtopogon nebulo OS., H 1.

Cyrtopogon rufitarsus Back., C 2.

Dasyllis astur OS., H 1.

Dasyllis cinerea Back, C 2.

Dasyllis fernaldi Back, C 1.

Dicolonus sparsipilosus Back, C 1.

Echthodopa pubera Loew, H 1.

Elachiptera dispar Willst. (Gaurax anchora Loew?), C 1.

Heteropogon johnsoni Back, C 2, P 2.

Laphria vultur OS., H 1.

Lasiopogon terricola Johns., M 2.

Leptogaster badius Loew, H 1.

Leptógaster pictipes Loew, H 1.

Promachus fitchii OS., H 3.

Stichopogon abdominalis Back, C 1. 
Mounted on slides :

Cecidomyia foliora Russ. \& Hook., C 10, P 23.

\section{HYMENOPTERA}

Pinned specimens:

Athyredon atriventris Cress., $\mathrm{H} 1$.

Bombus affinis Cress. worker, $\mathrm{H} 2$.

Bombus appositus Cress. female 2 ; worker $2, \mathrm{H} 4$.

Bombus atrifasciatus Morr. female (kirbyellus), T 1.

Bombus comsimilis Cress. female; worker (vagans), H 2.

Bombus cooleyi Morr. female (edwardsii var.), T 1, C 1.

Bombus cooleyi var. B. Morr. female (edwardsii var.), T 1.

Bombus dorsalis Cress. female; worker (fervidus var.), H 2.

Bombus edwardsii Cress. female 2; worker 2, H 4.

Bombus mixtus Cress. female, $\mathrm{H} 1$.

Bombus monardæ Ckll. female, M? 1.

Bombus nevadensis Cress. female; worker, H 2.

Bombus nevadensis aztecus Ck1l. female (fervidus var, dorsalis), M? 1.

Bombus prunellæ Ck11. female 1; worker 2, M? 3.

Bombus ridingsii Cress. female 2; worker 2, $\mathrm{H} 4$.

Bombus rufocinctus Cress. male, $\mathrm{H} 2$.

Bombus scutellaris Cress. female 2 ; worker $1, \mathrm{H} 3$.

Bombus separatus Cress. female 3 ; worker 1 ; male $1, \mathrm{H} 5$.

Ceratina imarta Cress., H 1.

Chlorion (Proterosphex) ashmeadi H. Fern., C 2.

Encyrtus thyreodontis Ash., P, 1 lot.

Enicospilus arcuatus Felt., C 1.

Enicospilus neotropicus Hook., C 1.

Enicospilus purgatus arcuatus Felt., C 1, M 1, H 1.

Enicospilus thoracicus Cress., H 1.

Eremotylus flavofuscus radialis Hook., C 2.

Eremotylus texanus Ash., H 1.

Isodontia exornata H. Fern. (Chlorion exornatum), C 1.

Isodontia macrocephala cinerea H. Fern. (Chlorion aztecum cinereum) C 1.

Lampronota americana Cress., H 1.

Lampronota scutellaris Cress., H 1.

Megachile sapellonis Ckll., C 1.

Mutilla nestor Fox, H 1.

Ophion słossonæ Davis, H 1.

Panurginus æthiops Cress., H 1.

Phytodietus vulgaris Cress., $\mathrm{H} 1$.

Psithyrus ashtoni Cress. female, H 2.

Psithyrus latitarsus Morr. female, T 1, C 5.

Psithyrus variabilis Cress. female, $\mathrm{H} 2$.

Sphex abdominalis Cress. female (Chlorion), T 1.

Sphex abdominal Cress. female (Chlorion), T 1.

Sphex bridiwelli H. Fern. (Chlorion), C 1, P. 1. 
Sphex dubitata Cress. (Chlorion), H 2.

Sphex (Priononyx) ferrugineus Fox male (Chlorion), C 1.

Sphex (Priononyx) ferrugineus Fox female (Chlorion), H 1.

Sphex læviventris Cress. (Chlorion), H 2.

Sphex lauta Cress. (Chlorion), H 1.

Sphex (Isodontia) macrocephalus Fox (Chlorion aztecum Sauss), H 1.

Sphex nudus H. Fern (Chlorion), C 1, P 1.

Sphex texanus Cress. (Chlorion), H 1, M 1.

Tachysphex apicalis Fox, H 1.

Thyreodon grandis Cress., $\mathrm{H} 1$.

Thyreodon laticinctus Cress., H 2.

Thyreodon niger Cress., $\mathrm{H} 2$.

Trachandrena dolosa Vier., $\mathrm{P} 1$.

Trachandrena weedi Vier., P 2.

Vespa fernaldi Lewis, C 2, M 1. 


\section{A LIST OF THE ENTOMOLOGICAL PUBLICATIONS FROM THE MASSACHUSETTS AGRI- CULTURAL COLLEGE, to January 1, 1911}

In this list are included all publications on insects where the work was done entirely, or for the greater part, at the Massachusetts Agricultural College. Probably some papers have been overlooked; but at least it is an approximate list of the output in entomology since the beginning of Prof. Charles H. Fernald's connection with the college.

$188 \%$.

Fernald, C. H. North American Lepidoptera. Can. Ent., XIX, 98.

Vanessa antiopa. The Entomologist, XX, 228.

North American Pyralidæ. Ent. Am., III, $12 \%$.

Fernald, H. T. Notes on Erebus odora L. Ent. Am., III, 78.

1888.

Fernald, C. H. Review of "A Monograph of the Sphingidæ." Ent. Am., IV, 177.

North American Pyralidæ. Ent. Am., IV, 37.

Notes on the Crambidæ. Ent. Am., IV, 44.

On the Genus Diatræa. Ent. Am., IV, 119.

On the Genus Schoenobius. Ent. Am., IV, 135.

The Jumping Sumach Beetle \& the Bud Moth. Hatch Exp. Sta. Bull. No. 1.

The Grape-vine Leaf-hoppers, Ants and Currant Worm. Hatch Exp. Sta. Bull. No. 2.

The Orthoptera of New England.

Fernald, H. T. Early Stages of Erebus odora L. Ent. Am., IV, 36.

1889.

Fernald. C. H. North America Microlepidoptera. Ent. Am., V, 18. Letter. Ent. Am., V, 208.

On the date of publication of Walker's and Zeller's Crambidæ. Ent. Am., V, 215.

Household Pests. Hatch Exp. Sta. Bull. No. 5.

Special Bulletin. Hatch Exp. Sta. Bull.

The Gypsy Moth. Mass. Crop Report.

Report of the Entomologist. First Report Hatch Exp. Sta., 5. 
Fernald, C. H. Book Notice, The Phycitidæ of North America. Can. Ent., XXII, 191.

A Bit of History. Ent. Am., VI, 112.

A Dangerous Insect Pest in Medford. Hatch Exp. Sta. Bull. No. $\%$.

Book Notice, Meyrick's Pyralidina of Europe. Ent. Mon. Mag., I, 2d ser., 323.

Report of the Entomologist. Second Report Hatch Exp. Sta., 5.

1891.

Fernald, C. H. New North America Microlepidoptera. Can. Ent., XXIII, 29.

Report on Insects. Hatch Exp. Sta. Bull. No. 12.

Gypsy Moth. Mass. Crop Report, June.

Report of the Entomologist. Third Report Hatch Exp. Sta., 5.

1892.

Fernald, C. H. Hermaphrodite Gypsy Moths. Can. Ent., XXIV, 8\%. New North America Microlepidoptera. Can. Ent., XXIV, 121 \& 178.

Report on Insects. Hatch Exp. Sta. Bull. No. 19. Gypsy Moth Report, 25.

Report of the Entomologist. Fourth Report Hatch Exp. Sta., 148.

1893.

Fersald, C. H. New North America Microlepidoptera. Can. Ent., XXV, 94.

Report on Insects. Hatch Exp. Sta. Bull. No. 20.

Gypsy Moth Report, 38.

Fernald, C. H., Kirkland, A. H., Lounsbury, C. $P_{7^{*}}$ Report of the Entomologists. Fifth Report Hatch Exp. Sta., \%.

1894.

Fernald, C. H. Book Notice, Monographie des Phycitinæ et des Galleriinz. Can. Ent., XXVI, 52.

Entomological Notes. Can: Ent., XXVI, 344.

Microlepidoptera, Part I. Ent. News, V, 104.

North Greenland Microlepidoptera. Ent. News, V,

Microlepidoptera, Part II. Ent. News, V, 138.

Household Pests. Mass. Crop Report, Oct.

Gypsy Moth Report, 33. 
Fernald, C. H., Kirkland, A. H., Lounsbury, C. P. Report of the Entomologists. Sixth Report Hatch Exp. Sta., 5.

1895.

Fernald, C. H. . Gypsy Moth Report, $2 \%$.

Polyporus for Staging Insects. The Ent., XXVIII, 255.

Lounsbury, C. P. A New Greenhouse Pest. Appendix, 32d Ann. Report Mass. Agr. College, 112.

Cooley, R. A. Report of the Entomologist. Seventh Report Hatch Exp. Sta., 43.

1896.

Fernald, C. H. Insects Injurious to Evergreens. Ent. News, VII, $8 \%$.

Gypsy Moth in England. Ent. Mon. Mag., VII, N. S., 169.

Report of the Entomologist. Eighth Ann. Report Hatch Exp. Sta., 209.

The Crambidæ of North America. Appendix to Thirty-third Ann. Report Mass. Agr. Coll., 79. Gypsy Moth Report, 31.

Fernald, C. H., Forbush, E. H. The Gypsy Moth.

Cooley, R. A. Miscellaneous Insects. Hatch Exp. Sta. Bull. No. 36.

$189 \%$.

Fernald, C. H. Notes and News. Ent. News, VIII, 105.

The Spruce Gall Louse. Appendix to Thirty-fourth Ann. Report Mass. Agr. Coll., 185.

Gypsy Moth Report, 12.

Report of the Entomologist. Ninth Ann. Report Hatch Exp. Sta., 185.

Fernald, C. H., Kirkland, A. H. Brown-tail Moth. Special Bull. Hatch Exp. Sta.

Cooley, R. A. New Species of Chionaspis. Can. Ent., XXIX, 278. Burgess, A. F. Notes on Certain Coleoptera Known to Attack the Gypsy Moth. Gypsy Moth Report, 64.

1898.

Fernald, C. H. Report of the Entomologist. Tenth Ann. Report Hatch Exp. Sta., 264.

The Pterophoridæ of North America. Appendix to Thirty-fifth Ann. Report Mass. Agr. Coll.

Gypsy Moth Report, $1 \%$. 
Arsenate of Lead as an Insecticide. Gypsy Moth Report.

The Pterophoridæ of North America. Special Bull. Hatch Exp. Sta., Revised edition.

Cooley, R. A. New Species of Chionaspis and Notes on Previously Known Species. Can. Ent., XXXI, 85.

Diaspis amygdali in Massachusetts. Can. Ent., XXX, 232.

1899.

Fernald, C. H. Review of "A Natural History of the British Lepidoptera," Can. Ent., XXXI, 15\%.

Report of the Entomologist. Eleventh Ann. Report Hatch Exp. Sta., 182.

Gypsy Moth Report, 428.

Cooley, R. A. The Coccid Genera Chionaspis \& Hemichionaspis. Special Bull., Hatch Exp. Sta.

1900.

Fernald, C. H. On the North American Species of Choreutis and Its Allies. Can. Ent., XXXII, 236.

Zoölogy as Taught at the M. A. C. with Reference to Entomology. Ent. News, XI, 358.

Gypsy Moth Report, 352.

Fernald, C. H. \& H. T. Report of the Entomologists. Twelfth Ann. Report Hatch Exp. Sta., 204.

Fernald, H. T. Some Insects Injuring Market Garden Crops. Mass. Crop Report, May.

Spraying Mixtures. Nature Leaflet No. 4.

White-marked Tussock Moth. Nature Leaflet No. 5.

Spiny Elm Caterpillar. Nature Leaflet No. 6.

Eernald, H. T., Hinds, W. E. The Grass Thrips. Hatch Exp. Sta. Bull. No. $6 \%$.

Hinds, W. E. The Grass Thrips. Appendix to Thirty-seventh Ann. Report of Mass. Agr. Coll., 83.

1901.

Fernald, C. H. Marginal Wing Bristles in Lepidoptera. The Ent., XXXIV, 146.

New Pyralidæ and Tortricidæ from Palm Beach, Fla. Journ. N. Y. Ent. Soc., IX, 49.

Fernald, C. H. \& H. T. Report of the Entomologists. Thirteenth Ann. Report Hatch Exp. Sta., 172.

Fernald, H. T. The Elm Leaf Beetle. Hatch Exp, Sta. Bull. No. 76.

The May Beetle. Nature Leaflet No. 8. 
Hinds, W. E. Notes on the Life History of Alsophila pometaria. Can. Ent., XXXIII, 185.

Strength of Passalus cornutus Fab. Ent. News, XII, $25 \%$.

1902.

Fernald, Mrs. C. H. On the Genus Lecanium. Can. Ent., XXXIV, 177.

On the Type of the Genus Coccus L. Can. Ent., XXXIV, 232.

FERnALD, C. H. \& H. T. Report of the Entomologists. Fourteenth Ann. Report Hatch Exp. Sta., 86.

Fernald, H. T. Three Common Orchard Scales. Mass. Crop. Report, June.

Fernald, H. T., Stone, G. E., Maynard, S. T. Fungicides, Insecticides, and Spraying Calendar. Hatch Exp. Sta. Bull. No. 80.

Hinds, W. E. Contribution to a Monograph of the Insects of the Order Thysanoptera Inhabiting North America. Proc. U. S. Nat. Mus., XXVI, $79-242$.

1903.

Fernald, C. H. Book Notice, A Natural History of the British Lepidoptera. Can. Ent., XXXV, 23.

Color Blindness Among Entomologists. Can. Ent., XXXV, 206.

Fernald, C. H. \& H. T. Report of the Entomologists. Fifteenth Ann. Report Hatch Exp. Sta., 119.

Fernald, C. H., Kirkland, A. H. The Brown-tail Moth.

Fernald, H. T. Notes on the North American Species of Isodontia, Patton, with Descriptions of a New Species and Variety. Can. Ent., XXXV, 269.

How Shall We Arrange Our Collections? Ent. News, XIV, 108.

Two New Species of Sphex. Psyche, X, 201.

Plant Lice or Aphids. Nature Leaflet No. 18.

Orchard Treatment for the San José Scale. Hatch Exp. Sta. Bull. No. 86.

Some Important Scale Insects. Mass. Crop. Report, Sept.

First Ann. Report State Nursery Inspector.

Fernald, H. T., Back, E. A. The Plum Webbing Sawfly. Ent. News, XIV, 298.

Fernald, Mrs. C. H. Notes on the Coccidæ. Can. Ent., XXXV, 22. Lepidosaphes versus Mytilaspis. Can. Ent., XXXV, 90.

A Catalogue of the Coccidæ of the World. Hatch Exp. Sta. Bull. No. 88. 
Franklin, H. J. Notes on Acanthothrips. Psyche, X, 221.

Morrill, A. W. Notes on some Aleyrodes from Massachusetts, with Descriptions of New Species. Psyche, X, 80.

Life History and Description of the Strawberry Aleyrodes, Aleyrodes packardi, n. sp. Can. Ent., XXXV, 25.

Notes on the Early Stages of Corylophodes marginicollis Lec. Ent. News, XIV, 135.

The Greenhouse Aleyrodes. Strawberry Aleyrodes. Tech. Bull. No. 1, Hatch Exp. Sta.

1904.

Fernald, C. H. On the Genus Proteopteryx. Can. Ent., XXXVI, 120.

A New Genus and Species of North American Choreutinæ. Can. Ent., XXXVI, 130.

Fernald, C. H. \& H. T. Report of the Entomologists. Sixteenth Ann. Report Hatch Exp. Sta., 105.

Fernald, H. T. Second Annual Report State Nursery Inspector.

The North American Species of Chlorion. Ent. News, XV., $11 \%$.

Fernald, H. T., Stone, G. E., Waugh, F. A. Fungicides, Insecticides and Spraying Calendar. Hatch Exp. Sta. Bull. No. 96.

Back, E. A. New Species of North American Asilidæ. Can. Ent., XXXVI, 289.

Hodgkiss,H. E. The Common Palm Scale. Appendix to Forty-first Ann. Report Mass. Agr. Coll.

1905.

Fernald, C. H. A New Species of North American Proteoteras. Can. Ent., XXXVII, 16.

North American Tortricidæ. Can. Ent., XXXVII, 399.

On Acleris heindelana n. sp. Am. Nat., XXXIX, 468.

Dates of Hubner's "Sammlung." Privately printed.

Fernald, C. H. \& H. T. Report of the Entomologists. Seventeenth Ann. Report Hatch Exp. Sta., 111.

Fernald, H. T. The Datanas. Nature Leaflet No. 10.

The Type of the Genus Sphex. Ent. News, XVI, 163.

Different Kinds of Types. Ent. News, XVI, 196.

Third Annual Report State Nursery Inspector.

Franklin, H. J. A New Species of Entomobrya. Ent. News, XVI, \%ช. 
Hood, C. E. Circular No. 3, The Apple Maggot or Railroad Worm.

Circular No. 4, Wire Worms.

Circular No. 6, The Lecaniums or Soft Scales.

Circular No. \%, Ants.

1906.

Fernald, Mrs. M. E. The Type of the Genus Coccus. Can. Ent., XXXVIII, 125.

Fernald, C. H. Report of the Entomologist. First Ann. Report of the Supt. Gypsy and Brown-tail Moths, 105.

Fernald, C. H. \& H. T. Report of the Entomologists. Eighteenth Ann. Report Hatch Exp. Sta., 258.

Three Common Scale Insects. Nature Leaflet, No. 33.

Fourth Annual Report State Nursery Inspector.

The Digger. Wasps of North America and the West Indies Belonging to the Subfamily Chlorioninæ. Proc. Nat. Mus., XXXI, 291-423.

Tower, W. V. A New Method of Preparing Wings and Other Parts of Insects for Study. Ent. News, XVII, 218.

$190 \%$.

Fernald, C. H. Entomological Report. Second Ann. Report of the Supt. Gypsy and Brown-tail Moths, $11 \%$.

Fernald, C. H. \& H. T. Report of the Entomologists. Nineteenth Ann. Report Mass. Agl. Exp. Sta., 316.

Fernald; H. T. The Oriental Moth. Hatch Exp. Sta. Bull. No. 114. The San José Scale. Mass. Agl. Exp. Sta. Bull. No. 116.

Nature Leaflet No. 33 revised.

Circular No. 2, Cutworms.

Circular No. 5, Root Maggots.

Greenhouse Pests. Mass. Crop Report, Oct.

Fifth Annual Report State Nursery Inspector.

A New Locustid from Nantucket. Psyche, XIV, 120.

A Collection of Chlorionin: from Argentine. Bull. Mus. Comp. Zool. L, 9.

Fernald, H. T. Summers, J. N. The Early Stages of the Oriental Moth. Ent. News, XVIII, 321.

Franklin, H. J. Notes- on Certain Cranberry Bog Insects. Ent. News, XVIII, $1 \%$.

Notes on Bombinæ with Descriptions of New Species. Ent. News, XVIII, 90.

Ctenothrips, new genus. Ent. News, XVIII, $24 \%$.

Cranberry Insects. Mass. Agl. Exp. Sta. Bull. No. 115. 
Fernald, C. H. Notes on Erebus odoratus L. Ent. News, XIX, 260.

The Genera of the Tortricidæ and their Types; 68 pages. Privately printed.

A New Species of Tortricidæ. Can. Ent., XL, 349.

Fernald, C. H. \& H. T., Summers, J. N. Report of the Entomologists. Twentieth Ann. Report Mass. Agl. Exp. Sta., 151.

Fernald, H. T. The Future of Economic Entomology. Pop. Sci. Monthly, LXXII, $1 \%$.

Massachusetts Fruit Trees and Their Insect Foes. Fifty-fifth Ann. Report Mass. Board of Agr.

Sixth Annual Report State Nursery Inspector.

The Fundamental Principles of Spraying. Journ. Econ. Ent., I, 265.

Greenhouse Pests and Their Control. Fifty-fifth Ann. Report Mass. State Board of Agr.

Fernald, H. T., Stone, G. E. Fungicides, Insecticides and Spraying Directions. Mass. Agl. Exp. Sta. Bull. No. 123.

Fernald, H. T., Stone, G. E. Start, E. A. Shade Trees. Mass. Agl. Exp. Sta. Bull, No. 125.

Franklin, H. J. How to Fight Cranberry Insects. Mass. Agl. Exp. Sta. Bull. No. 126.

Russelt, H. M., Hooker, C. W. A New Cecidomyiid on Oak. Ent. News, XIX, 249.

Hood, C. E. The White Fly. Circular No. 19.

1909.

Fernald, C. H. \& H. T., Summers, J. N. Report of the Entomologists. Twenty-first Ann. Report Mass. Agl. Exp. Sta., Part II, 59.

Fernald, H. T. Fumigation Dosage for Forcing Crops. Twentyfirst Ann. Report Mass. Agl. Exp. Sta., Part I, 73.

Insects of the Year. Twenty-first Ann. Report Mass. Agl. Exp. Sta., Part I, 75.

A Parasite on the Asparagus Beetle. Journ. Econ. Ent., II, 278.

A New Treatment for Wireworms. Journ. Econ. Ent., II, 279.

A Parasite of the Asparagus Beetle. Circular No. 23, Mass. Agl. Exp. Sta.

Seventh Annial Report State Nursery Inspector.

Frost, C. A., Summers, J. N. The Food Plant of Enarmonia tristrigana, Clemens. Psyche, XVI, 13.

Hooker, C. W. The periodical cicada in Massachusetts. Twentyfirst Ann. Report Mass. Agl. Exp. Sta., 200. 
1910.

Fernald, C. H. \& H. T., Summers, J. N. Report of the Entomologists. Twenty-second Ann. Report Mass. Agl. Exp. Sta., Part II, 73.

Fernald, H. T. Nursery Inspection in Massachusetts. Journ. Econ. Ent., III, 272.

Insects of the Year. Twenty-second Ann. Report Mass. Agl. Exp. Sta., Part I, 70.

Review of Bulletin No. 131, Bur. Chem., U. S. Dept. Agr. Journ. Econ. Ent., III, 322.

The New Entomological Building at the Massachusetts Agricultural College. Journ. Econ. Ent., III, 445 .

Hooker, C. W., Tower, W. V. Fumigation Dosage. Twenty-second Ann. Report Mass. Ag1. Exp. Sta., Part I, 214.

Whitmarsh, R. D. North American Paniscini. Ann. Ent. Soc. Am., III, 186. 


\section{PROFESSIONAL ENTOMOLOGISTS WHO HAVE STUDIED AT THE MASSACHUSETTS AGRICULTURAL COLLEGE*}

Felt, E. Porter, B. Sc., 1891, D. Sc., (Cornell) 1894. New York State Entomologist, Albany, N. Y.

Knight, Jewell B., B. Sc., 1892, M. Sc., 1901. Director Experiment Station, Poona College, Poona, India.

Kirkland, Archie H., B. Sc., 1894, M. Sc., 1896. With U. S. Bureau of Entomology on Alfalfa Weevil work in Utah. Washington, D. C.

Lounsbury, Charles, P., B. Sc., 1894. Government Entomologist, Cape Town, South Africa.

Ballou, Henry A., B. Sc., 1895, M. Sc., 1906. Government Entomologist, British West Indies, Barbados, B. W. I.

Burgess, Alfred F., B. Sc., 1895, M. Sc., 189\%. With U. S. Bureau of Entomology, Gipsy Moth Parasite Laboratory, Melrose Highlands, Mass.

Cooley, Robert A., B. Sc., 1895. Prof. of Zoölogy and Entomology, Montana Agl. College, and State Entomologist, Bozeman, Mont.

Frost, Harol.d L., B. Sc., 1895. Landscape Forester and Entomologist, Arlington, Mass.

Caudell, Andrew N., B. Sc., (Oklahoma) 1896. Graduate student in Entomology Mass. Agl. College, Amherst, Mass., $189 \%$. Custodian of Orthoptera, U. S. National Museum, Washington, D. C.

Hinds, Warren E., B. Sc., 1899, Ph. D., 1902. Prof. of Entomology, and Station Entomologist, Alabama Polytechnic Institute, Auburn, Ala.

Hooker, William A., B. Sc., 1899. Assistant Editor (Entomology) Experiment Station Record, U. S. Dept. Agr., Washington, D. C.

Morrill, Austin W., B. Sc., 1900, Ph. D., 1903. Entomologist Arizona Agl. Experiment Station and Horticultural Commission, Phoenix, Ariz.

Hodgkiss, Harold E., B. Sc., 1902. Assistant Entomologist, N. Y. Ag1. Experiment Station, Geneva, N. Y.

*Revised to Jan. 1, 1911. 
Franklin, Henry J., B. Sc., 1903, Ph. D., 1908. In charge of Cranberry Investigations, Mass. Agl. Experiment Station, Amherst, Mass.

Tower, Winthrop V., B. Sc., 1903. Entomologist, Porto Rico Agl. Experiment Station, Mayaguez, Porto Rico.

Back, Ernest A., B. Sc., 1904, Ph. D., 190\%. Entomologist, Va. Agl. Experiment Station, and State Entomologist, Blacksburg, Va.

Hood, Clarence E., B. Sc., 1906. With U. S. Bureau of Entomology, Crowley, La.

Russell, Harry M., B. Sc., 1906. With U. S. Bureau of Entomology, Compton, Cal.

Hooker, Charles W., B. A. (Amherst) 1906, Ph. D., 1909. With U. S. Bureau of Entomology, Washington, D. C.

Peters, Frederick C., B. Sc., 190\%. Landscape Forester and Entomologist, Ardmore, $\mathrm{Pa}$.

Summers, John N., B Sc., 190\%. Graduate student and Assistant, Mass. Agl. College, Amherst, Mass.

Wood, Herbert P., B. Sc., 190\%. With U. S. Bureau of Entomology, Box 208, Dallas, Tex.

Gowdey, Clinton C., B. Sc., 1908. Government Entomologist, Uganda Protectorate, British East Africa.

Hyslop, JAmes A., B. Sc., 1908. ${ }^{*}$ With U. S. Bureau of Entomology, Pullman, Wash.

Johnston, Frederick A., B. Sc., 1908. With U. S. Bureau of Entomology. Truck Crop Experiment Station, Norfolk, Va.

Jones, Thomas H., B. Sc., 1908. With U. S. Bureau of Entomology, Washington, D. C.

Parker, John R., B. Sc., 1908. Assistant Entomologist, Montana Agl. Experiment Station, Bozeman, Mont.

Regan; William S., B. Sc., 1908. Graduate student in Entomology, Mass. Ag1. College, Amherst, Mass.

Turner, Wliliam F., B. Sc., 1908. Assistant Entomologist, Alabama Agl. Experiment Station, Auburn, Ala.

Whitmarsh, Raymond D., B. Sc., 1908. Assistant Entomologist, Ohio Agl. Experiment Station, Wooster, Ohio.

Bourne, Arthur I., A. B. (Dartmouth) 190\%. Graduate student in Entomology and Assistant in Entomology, Mass. Agl. Experiment Station, Amherst, Mass.

Bartlett, Oscar C., B. Sc., 1909. Graduate student in Entomology, Mass. Agl. College, Amherst, Mass. 
Caffrey, Donald J., B. Sc., 1909. Assistant Entomologist, Conn. Agl. Experiment Station, New Haven, Conn.

Cardin, Patricio P., B. Sc., 1909. Chief, Dept. Entomology and Vegetable Pathology, Estacion Agronomica, Santiago de las Vegas, Cuba.

Crossman, Samuel S., B. Sc., 1909. Graduate student in Entomology, Mass. Agl. College, Amherst, Mass.

Smulyan, Marcus T., B. Sc., 1909. Graduate student in Entomology, Mass. Agl. College, Amherst, Mass.

Merrill, Joseph H., B. Sc., (Dartmouth) 1905. Graduate student in Entomology, Mass. Ag1. College, Amherst, Mass.

Allen, Rodolphus H., B. Sc., 1910. Graduate student in Entomology, Mass. Agl. College, Amherst, Mass.

McLaine, Leonard S., B. Sc., 1910. Graduate student in Entomology, Mass. Agl. College, Amherst, Mass.

Thomas, Frank L., B. Sc., 1910. Graduate student in Entomology, Mass. Agl. Cóllege, Amherst, Mass. 
. 

Gaylord Bros. Makers

Syracuse, N. Y.

PAT. JAK. 21, 1908

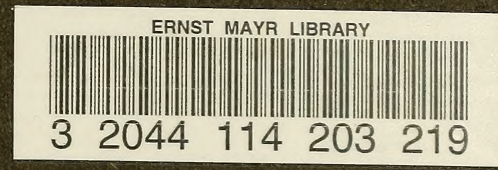


